In Cooperation With the Federal Emergency Management Agency and the Indiana Department of Natural Resources, Division of Water

\title{
Flood of September 2008 in Northwestern Indiana
}

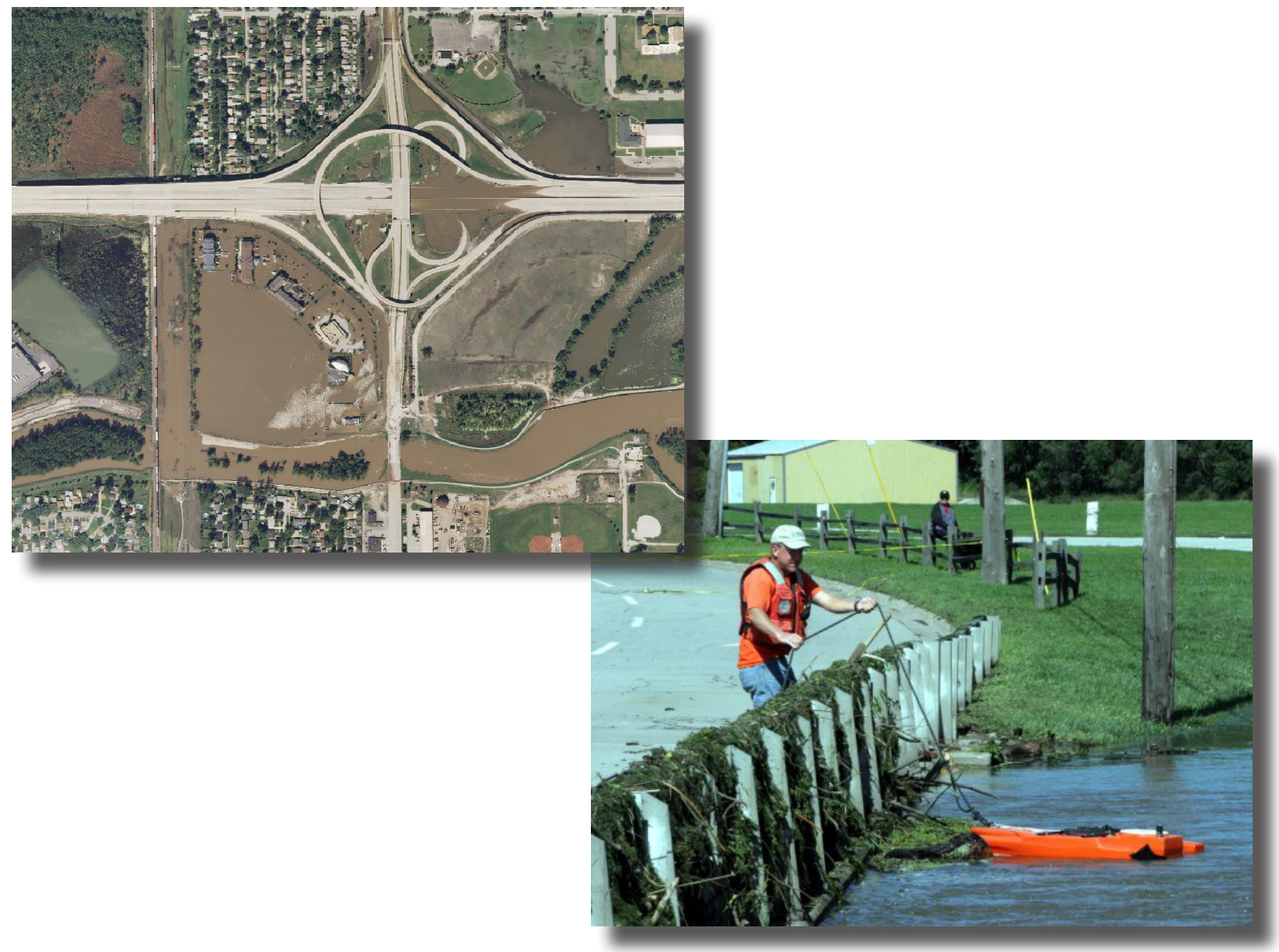

Open-File Report 2010-1098 


\section{Cover images}

Left-Little Calumet River south of Interstate 80 and the Kennedy Avenue Interchange at Hammond, Ind., September 16, 2008. (Aerial photo, at 1:14,000 scale, courtesy of the U.S. Army Corps of Engineers.)

Right-Discharge measurement made by Acoustic Doppler Current Profiler on Deep River at Lake George Outlet at Hobart, Ind., U.S. Geological Survey station 04093000. (Photograph by Ron G. Knapp, U.S. Geological Survey.) 


\section{Flood of September 2008 in Northwestern Indiana}

By Kathleen K. Fowler, Moon H. Kim, Chad D. Menke, and Donald V. Arvin

In Cooperation With the Federal Emergency Management Agency and the Indiana Department of Natural Resources, Division of Water

Open-File Report 2010-1098 


\title{
U.S. Department of the Interior \\ KEN SALAZAR, Secretary \\ U.S. Geological Survey \\ Marcia K. McNutt, Director
}

\section{U.S. Geological Survey, Reston, Virginia: 2010}

\author{
For more information on the USGS — the Federal source for science about the Earth, its natural and living resources, \\ natural hazards, and the environment, visit http://www.usgs.gov or call 1-888-ASK-USGS \\ For an overview of USGS information products, including maps, imagery, and publications, \\ visit http://www.usgs.gov/pubprod \\ To order this and other USGS information products, visit http://store.usgs.gov
}

\begin{abstract}
Any use of trade, product, or firm names is for descriptive purposes only and does not imply endorsement by the U.S. Government.

Although this report is in the public domain, permission must be secured from the individual copyright owners to reproduce any copyrighted materials contained within this report.
\end{abstract}

Suggested citation:

Fowler, K.K., Kim, M.H., Menke, C.D., and Arvin, D.V., 2010, Flood of September 2008 in Northwestern Indiana: U.S. Geological Survey Open File Report 2010-1098, 20 p. 


\section{Acknowledgments}

This report presents a compilation of information supplied by many agencies and individuals. David Knipe and Suzie Delay of the Indiana Department of Natural Resources, Division of Water, are acknowledged for technical support, expertise, and advice during this study. The authors also acknowledge the support and contributions of AI Shipe of the National Weather Service, Indianapolis Weather Forecast Center; William Morris and William Nelson of the National Weather Service, Chicago Weather Forecast Center; Jan Crider, Manuela Johnson, and Mary Moran of the Indiana Department of Homeland Security; and Kenneth Hinterlong of the Federal Emergency Management Agency Region V, Mitigation Section. The authors would also like to thank the Indiana Department of Natural Resources, Division of Water Surveying Section; the Federal Emergency Management Agency Joint Field Office; and the Indiana Silver Jackets Hazard Mitigation Taskforce for their assistance with this study. Rick D. Ackerson and John Ennis with the U.S. Army Corps of Engineers were of great help in defining areas of inundation along the Little Calumet River. Richard Eberle with the Town of Dyer; Aj Bytnar, City Planner of Hobart; Denise Sulek, Planning and Building Department, Town of Schererville; Kenneth Purze, La Porte County Drainage Board; and Kevin Breitzke, Porter County Surveyor, are thanked for reviewing inundation maps for their areas.

Michael Eberle of the U.S. Geological Survey is acknowledged for his timely editorial assistance with the report, and Pamela Lombard, Bret Robinson, and William Bartlett of the U.S. Geological Survey are acknowledged for their timely and thorough review of technical aspects of this study. The many hydrologists and hydrologic technicians from the U.S. Geological Survey Indiana Water Science Center who assisted with field and office aspects of the project also are acknowledged. 


\section{Contents}

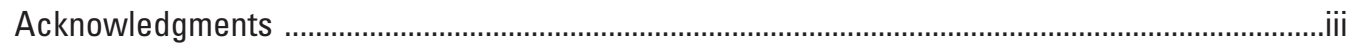

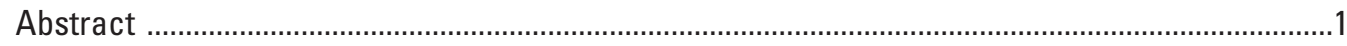

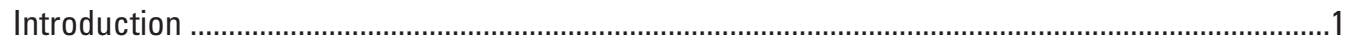

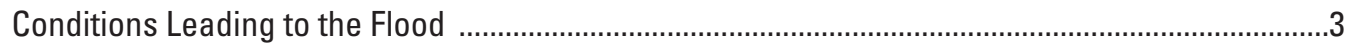

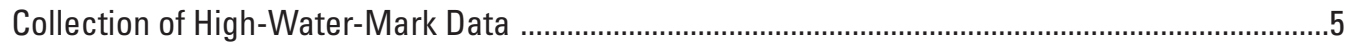

Methods of Estimating the Magnitudes and Annual Exceedance Probabilities of Peak

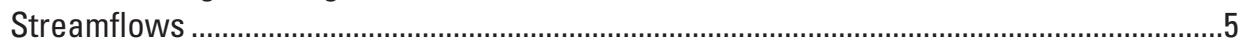

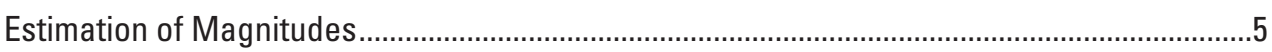

Estimation of Annual Exceedance Probabilities..........................................................................8

Estimated Magnitudes and Annual Exceedance Probabilities of Peak Streamflows for the

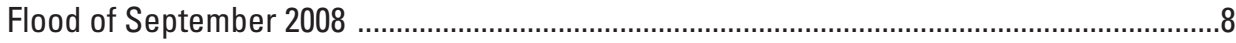

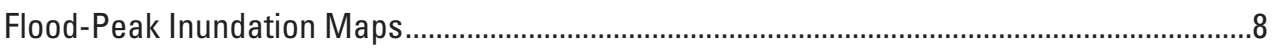

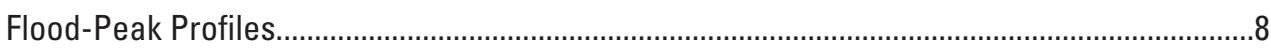

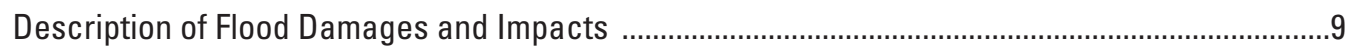

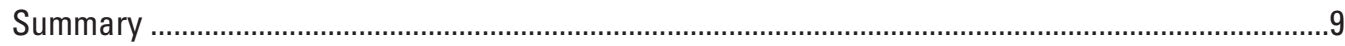

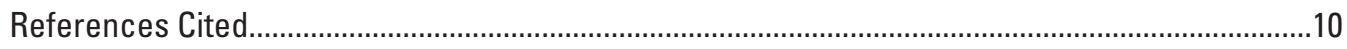

Glossary................................................................................................................................................11

Appendix 1. Site Descriptions and High-Water Marks at Study Sites, Flood of September 2008, Indiana.......................................................................................................................... 12

Appendix 2. Flood-Peak Inundation Maps for Selected Study Streams and Communities, Flood of September 2008, Indiana. ....................................................................................16

Appendix 3. Flood-Peak Elevation Profiles for Selected Sites, Flood of September 2008, Indiana.

\section{Figures}

1. Map showing study area in northwestern Indiana ...........................................................

2. Map showing distribution of rainfall totals September 12-15, 2008, and rainfall totals for the National Weather Service stations listed in table 1......................................4

3. Graph showing cumulative daily rainfall during September 11-16, 2008 in northwestern Indiana.................................................................................................

4. Map showing locations of selected U.S. Geological Survey streamgages.......................7

\section{Tables}

1. Total rainfall for September 12-15, 2008, and average-recurrence-interval rainfalls for a 4-day duration at selected National Weather Service precipitation stations in Indiana.

2. Flood-peak gage heights, peak streamflows, and annual exceedance probability of peak streamflows during the flood of September 2008 at selected U.S. 


\section{Conversion Factors, Datums, Abbreviations, and Acronyms}

\begin{tabular}{lcl}
\hline & Multiply & \multicolumn{1}{c}{ Bo obtain } \\
\hline & Length & \\
\hline inch (in.) & 2.54 & centimeter $(\mathrm{cm})$ \\
inch (in.) & 25.4 & millimeter $(\mathrm{mm})$ \\
foot (ft) & 0.3048 & meter $(\mathrm{m})$ \\
mile (mi) & 1.609 & kilometer $(\mathrm{km})$ \\
\hline & Area & square meter $\left(\mathrm{m}^{2}\right)$ \\
\hline acre & 4,047 & hectare $(\mathrm{ha})$ \\
\hline acre & 0.4047 & cubic decimeter $\left(\mathrm{dm}^{3}\right)$ \\
\hline & Volume & cubic meter $\left(\mathrm{m}^{3}\right)$ \\
\hline cubic foot $\left(\mathrm{ft}^{3}\right)$ & 28.32 & \\
cubic foot $\left(\mathrm{ft}^{3}\right)$ & 0.02832 & cubic meter per second $\left(\mathrm{m}^{3} / \mathrm{s}\right)$ \\
\hline & Flow rate & meter per hour $(\mathrm{m} / \mathrm{h})$ \\
\hline cubic foot per second $\left(\mathrm{ft}^{3} / \mathrm{s}\right)$ & 0.02832 & \\
inch per hour $(\mathrm{in} / \mathrm{h})$ & 0.0254 & \\
\hline
\end{tabular}

Vertical coordinate information is referenced to the North American Vertical Datum of 1988 (NAVD 88) or the National Geodetic Vertical Datum of 1929 (NGVD 29).

Horizontal coordinate information is referenced to the North American Datum of 1983 (NAD 83).

Altitude, as used in this report, refers to distance above the vertical datum.

\section{ACRONYMS}
AML Arc Macro Language
DEM Digital Elevation Model
FEMA Federal Emergency Management Agency
FSSA Family and Social Services Administration
GIS Geographic Information System
IDHS Indiana Department of Homeland Security
IDND Indiana Dunes National Lakeshore
IDNR Indiana Department of Natural Resources
NCDC National Climatic Data Center
NOOA National Oceanic and Atmospheric Administration
NWS National Weather Service
ONA Other Needs Assistance
TIN Triangular Irregular Network
USGS United States Geological Survey 


\title{
Flood of September 2008 in Northwestern Indiana
}

\author{
By Kathleen K. Fowler, Moon H. Kim, Chad D. Menke, and Donald V. Arvin
}

\section{Abstract}

During September 12-15, 2008, rainfall ranging from 2 to more than 11 inches fell on northwestern Indiana. The rainfall resulted in extensive flooding on many streams within the Lake Michigan and Kankakee River Basins during September 12-18, causing two deaths, evacuation of hundreds of residents, and millions of dollars of damage to residences, businesses, and infrastructure. In all, six counties in northwestern Indiana were declared Federal disaster areas.

U.S. Geological Survey (USGS) streamgages at four locations recorded new record peak streamflows as a result of the heavy rainfall. Peak-gage-height data, peak-streamflow data, annual exceedance probabilities, and recurrence intervals are tabulated in this report for 10 USGS streamgages in northwestern Indiana. Recurrence intervals of flood-peak streamflows were estimated to be greater than 100 years at six streamgages. Because flooding was particularly severe in the communities of Munster, Dyer, Hammond, Highland, Gary, Lake Station, Hobart, Schererville, Merrillville, Michiana Shores, and Portage, high-water-mark data collected after the flood were tabulated for those communities. Flood peak inundation maps and water-surface profiles for selected streams were made in a geographic information system by combining high-water-mark data with the highest resolution digital-elevation-model data available.

\section{Introduction}

Flood data are needed by Federal, State, and local agencies to make informed decisions in meeting mission requirements related to flood hazard mitigation, planning, and response. For example, the Federal Emergency Management Agency (FEMA), Indiana Department of Natural Resources (IDNR), and Indiana Department of Homeland Security (IDHS) need timely information on the magnitudes and recurrence intervals ${ }^{1}$ of floods to help respond to flood damage, enhance emergency response management, protect infrastructure, provide recovery guidance from the National

\footnotetext{
${ }^{1}$ Terms in bold type are defined in the glossary at the back of this report.
}

Flood Insurance Program and State regulatory programs, and plan for future flood events.

Heavy rains caused severe flooding during September 12-18, 2008, in parts of northwestern Indiana. Rainfall amounts from about 2 inches to more than 11 inches fell in northwestern Indiana on September 12-15 (National Climatic Data Center, 2008), causing the National Weather Service (NWS) to issue flash-flood warnings, areal flood warnings, and river flood warnings. During September 12-15, evacuations and water rescues were numerous in communities affected by the flooding. Flood impacts were particularly severe in communities in Lake, Porter, and La Porte Counties. The flooding caused two fatalities, major transportation disruptions, damage to thousands of homes and businesses, damage to dams and flood-control structures, and damage to critical facilities, including utilities and medical centers (Midwest Regional Climate Center, 2008). On September 20, 2008, Indiana Governor Mitchell E. Daniels, Jr., requested a major disaster declaration for parts of Indiana. Damage caused by the severe storms and flooding resulted in a Presidential Disaster Declaration on September 23, 2008, for six northwestern Indiana counties (Federal Emergency Management Agency, 2008a). Given the severity of the September 2008 flooding in Indiana, the U.S. Geological Survey (USGS), in cooperation with FEMA and IDNR, Division of Water, began this study to document the meteorological and hydrological conditions leading to the flood and to compile flood-peak gage heights, streamflows, annual exceedance probabilities, and recurrence intervals at USGS streamgages; construct flood profiles and flood peak inundation maps; and summarize flood damages and impacts.

The purpose of this report is to document the flood of September 2008. The meteorological and hydrologic conditions leading to the floods are discussed. Meteorological data were provided by the NWS and the Indiana State Climate Office, and hydrologic-condition information was obtained from streamflow data at USGS streamgages. Flood information is presented for 11 communities in the study area (fig.1). The communities include Munster, Dyer, Hammond, Highland, Gary, Hobart, Lake Station, Schererville, Merrillville, Michiana Shores, and Portage. Peak-gage-height and peak-streamflow data are presented for 10 USGS streamgages within the Lake Michigan Basin and the Kankakee River 
Basin. High-water marks set by the IDNR and the USGS were surveyed to obtain water-surface elevations for about 37 miles of streams. The streams include the Little Calumet River, Deep River, Turkey Creek, Hart Ditch, Robbins Ditch, Dyer Ditch, and White Ditch. The high-water-mark data were used to produce flood-peak inundation maps and flood profiles for selected streams in the communities studied. Information for the flood damage and impact summary was provided by FEMA, NWS, IDHS, IDNR, the Indiana Office of Disaster Recovery, local agencies, news accounts and photographs, and corroborated testimony from individuals in affected communities.

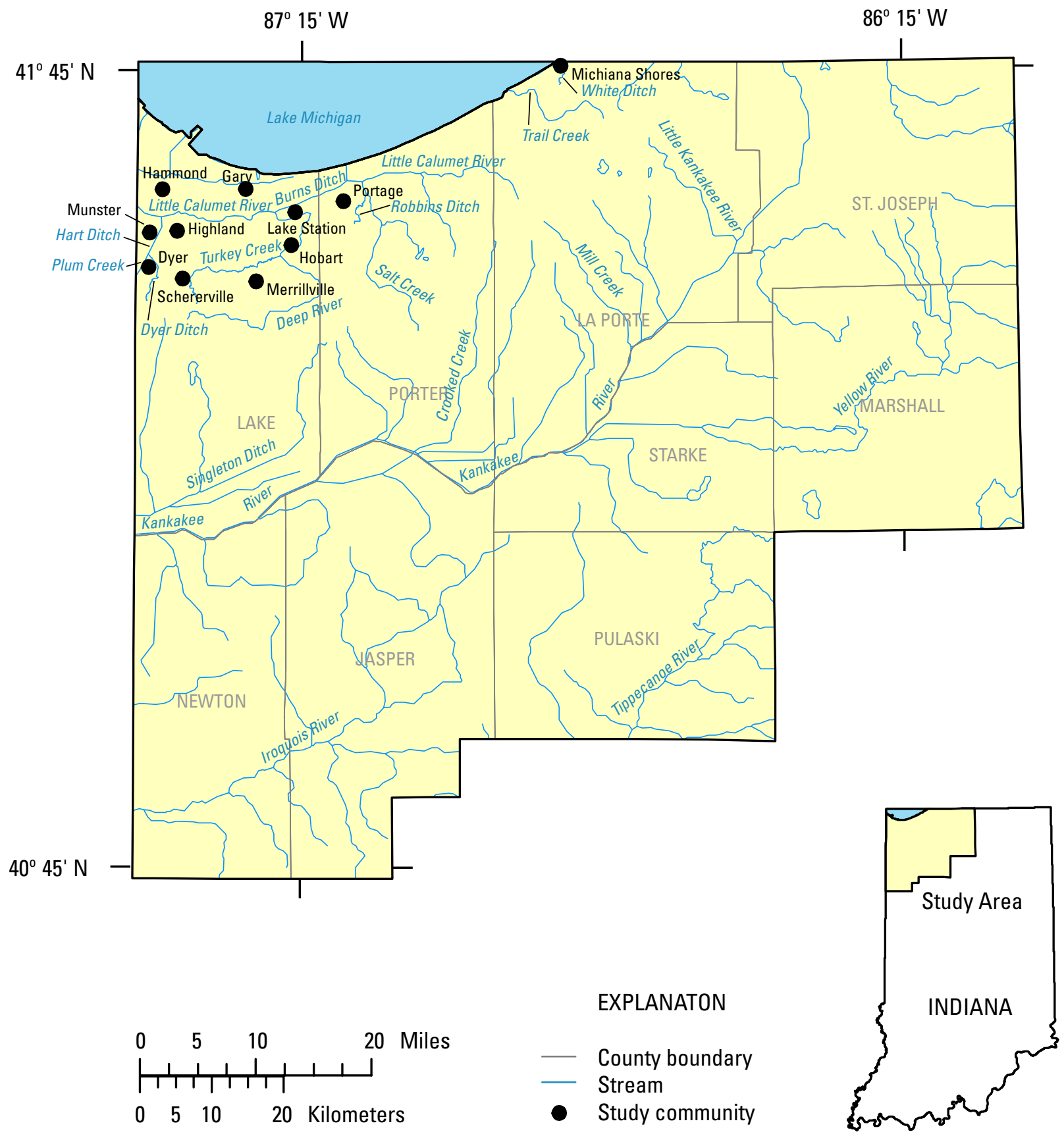

Figure 1. Study area in northwestern Indiana. 


\section{Conditions Leading to the Flood}

The September flooding in Indiana was caused by heavy rain falling on areas that had already received above-normal precipitation. A wetter than normal spring and late summer preceded the September flooding. Heavy rainfall in June caused record flooding in the central and southern parts of the state (Morlock and others, 2008). From January through August 2008, northwestern Indiana received 30.25 inches of rain, more than 4 inches above normal (Indiana State Climate Office, 2008a). In September this area received an average of 8.38 inches, 261 percent of normal (Indiana State Climate Office, 2008b). Early in September, the remnants of Hurricane Gustav drifted into the Midwest and merged with a cold front. During this event, 3 to 4 inches of rain fell in Illinois, Indiana, and into Michigan. About a week later, Hurricane Ike made landfall along the Texas Gulf Coast and brought additional rain to much of the same area as it followed a path similar to Hurricane Gustav's through the Midwest. The remnants of hurricanes Gustav and Ike drenched areas from Missouri through Indiana with up to 3 times the normal September rainfall amount. Northwestern Indiana was especially hard hit by flooding rains. Portage (Porter County) received 11.46 inches of rain between September 12 and 14, and South Bend (St. Joseph County) received 10.94 inches of rain in the same period (Midwest Regional Climate Center, 2008).

A map of estimated precipitation totals prepared from National Oceanic and Atmospheric Agency (NOAA) radar data (NCDC NEXRAD Data Inventory, 2008) shows rainfall totals ranging from about 1 inch to more than 10 inches for September 12-15 across northwestern Indiana (fig. 2). Total rainfall amounts from selected NWS precipitation stations (table 1, fig. 2) for the same period ranged from 7.4 in. at Lowell, Lake County, to 11.2 in. at La Porte, La Porte County. Average recurrence intervals ${ }^{2}$ (Bonnin and others, 2006) given in total rainfall amount in inches for a 4-day duration are presented in table 1. Average recurrence intervals were greater than 100 years at precipitation stations Crown Point 1N, Lake County, and Wanatah 2 WNW, Porter County; greater than 200 years at Kingsbury 1 N, La Porte County, and Valparaiso 5NNE, Porter County; and greater than 500 years at Indiana Dunes National Lakes (IDNL), Porter County, and LaPorte, La Porte County. A graph of daily cumulative rainfall (fig. 3) at seven NWS precipitation stations demonstrates the rainfall patterns for the 4-day period. For most of the stations listed in table 1, distribution of rainfall amounts throughout the 4-day period followed a pattern similar to that for the IDNL station (fig. 3).

\footnotetext{
${ }^{2}$ The recurrence interval is the average interval of time within which the given event will be equaled or exceeded once (American Society of Civil Engineers, 1953, p. 1221). For example, the 100 -year rainfall is the rainfall that would be exceeded or equaled, on long-term average, once in 100 years. Recurrence interval relates the magnitude of an event to a probability of occurrence and does not imply that the event will happen at regular intervals; for example, two 100-year floods can occur within the same year at the same location. The reciprocal of the recurrence interval is the annual exceedance probability, which is the probability that a given event magnitude will be exceeded or equaled in any given year (Hodgkins and others, 2007). For example, the annual exceedance probability of the 100 -year peak flood streamflow is 0.01 . In other words, there is a 1-percent chance that the 100year peak flow will be exceeded or equaled in any given year.
}

Table 1. Total rainfall for September 12-15, 2008, and average-recurrence-interval rainfalls for a 4-day duration at selected National Weather Service precipitation stations (figure 2) in Indiana.

[Total rainfall from National Oceanic and Atmospheric Administration (2008a). Average recurrence intervals from Bonnin and others (2006)]

\begin{tabular}{|c|c|c|c|c|c|c|c|}
\hline \multirow[b]{2}{*}{ Site name } & \multirow[b]{2}{*}{ County } & \multicolumn{6}{|c|}{ Average-recurrence-interval rainfall for 4-day duration (inches) } \\
\hline & & $\begin{array}{c}\text { Total } \\
\text { rainfall } \\
\text { (inches) }\end{array}$ & 50-year & 100-year & 200-year & 500-year & 1,000 -year \\
\hline Indiana Dunes Natl Lks & Porter & 10.8 & 7.1 & 7.9 & 8.8 & 10.1 & 11.2 \\
\hline Kingsbury $1 \mathrm{~N}$ & La Porte & 9.7 & 7.2 & 8.0 & 8.9 & 10.2 & 11.3 \\
\hline Valparaiso 5NNE & Porter & 9.8 & 7.3 & 8.2 & 9.1 & 10.5 & 11.6 \\
\hline Wanatah 2 WNW & Porter & 8.6 & 7.1 & 8.0 & 8.9 & 10.2 & 11.3 \\
\hline
\end{tabular}




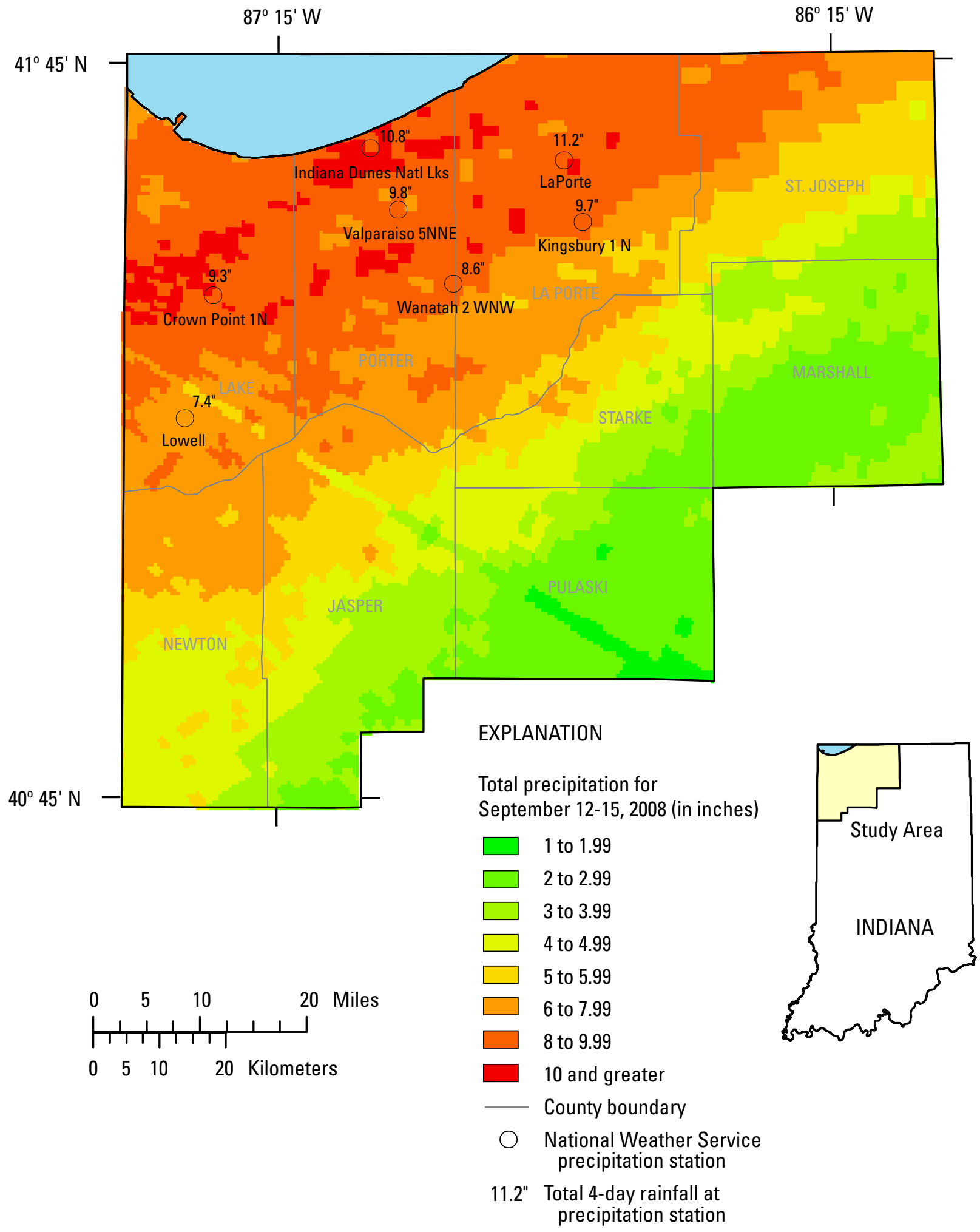

Figure 2. Distribution of rainfall totals September 12-15, 2008, and rainfall totals for the National Weather Service stations (by station name) listed in table 1. Rainfall-distribution data from the National Oceanic and Atmospheric Administration (2008b). 


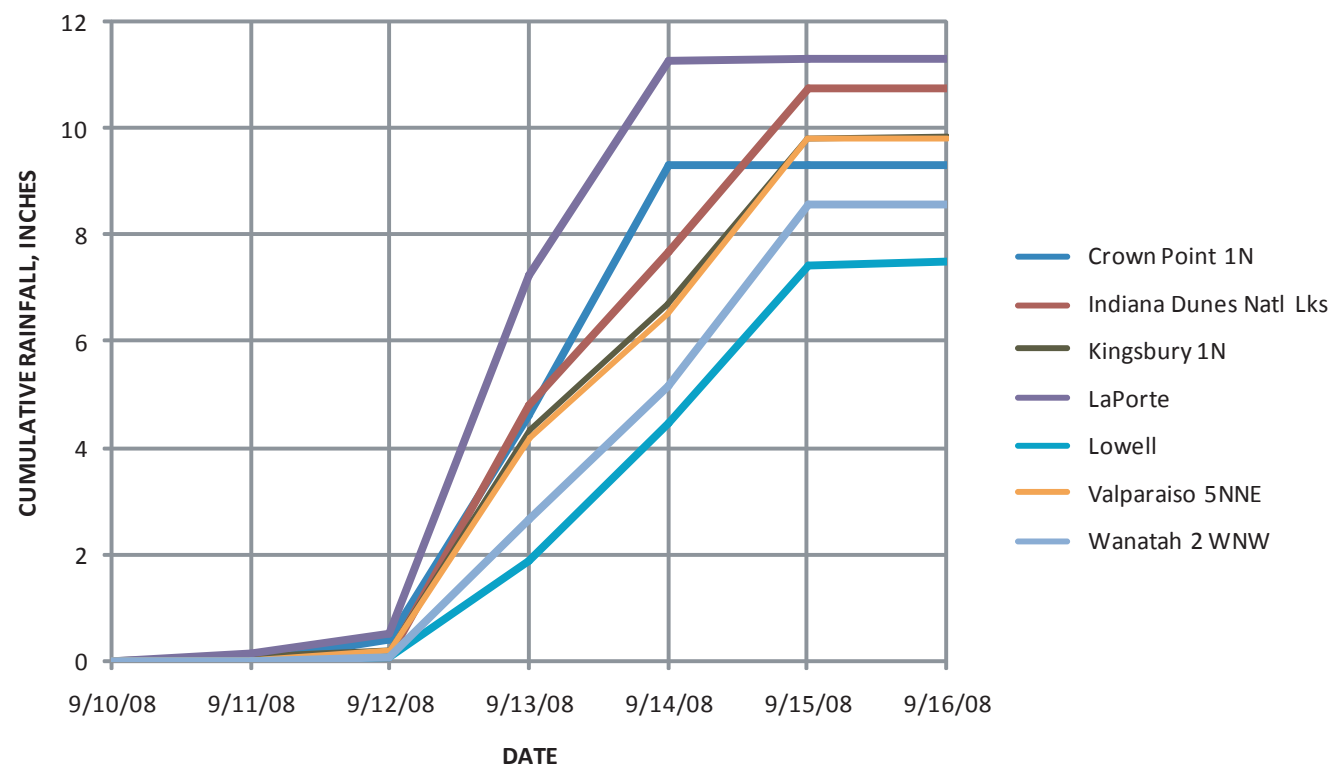

Figure 3. Cumulative daily rainfall during September 11-16, 2008, in northwestern Indiana (National Oceanic and Atmospheric Administration, 2008a).

\section{Collection of High-Water-Mark Data}

High-water marks were identified and flagged in the field by IDNR and USGS field crews after floodwaters receded. High-water marks were set along approximately 46 miles of streams after the floods. For this study, high-water marks were fully documented for about 37 stream miles on the following streams: Hart Ditch, Plum Creek, Dyer Ditch, the Little Calumet River, Turkey Creek, Deep River, Robbins Ditch, and White Ditch (fig.1). The IDNR, USGS, and IDHS collectively determined the areas where high-water marks were to be flagged in order to effectively document the flooding. The accuracy of high-water marks was rated subjectively by field personnel as "excellent," "good," "fair," or "poor" according to guidelines of Lumia and others (1986). "Excellent" means the reported high-water mark is within $0.02 \mathrm{ft}$ of the true highwater elevation; "good," within $0.05 \mathrm{ft}$; "fair," within $0.10 \mathrm{ft}$; and "poor," less than "fair" accuracy.

High-water marks at each site were surveyed to obtain peak-water-surface elevations referenced to North American Vertical Datum of 1988 (NAVD 88). High-water-mark descriptions, locations (latitude and longitude), and accuracy ratings are presented in appendix 1.

\section{Methods of Estimating the Magnitudes and Annual Exceedance Probabilities of Peak Streamflows}

\section{Estimation of Magnitudes}

Peak streamflows documented in this study were determined at 10 USGS streamgages (table 2, fig. 4) by use of the rating curve (the relation between river height and flow) for each station. Rating curves at streamgages are developed by relating gage height to streamflow for a range of flows (Rantz and others, 1982). Streamflow data points used to develop a rating are determined most commonly by direct measurement at the gage or, if direct measurement is not possible, by indirect methods. The rating curve is interpolated between streamflow data points and can be extrapolated beyond the highest streamflow data point; however, excessive extrapolation of the rating at high gage heights can result in large errors in streamflow (Sherwood and others, 2007).

Peak gage heights (table 2) were obtained either from electronic data recorders or from surveyed high-water marks where recorders or stage sensors either malfunctioned or were unavailable. The rating curve was used to compute peak streamflow (table 2) from peak gage height. Direct streamflow measurements, made during September 14-19, 2008 and during other periods of high flow in 2008, served as data points for rating-curve verification and extrapolation. 


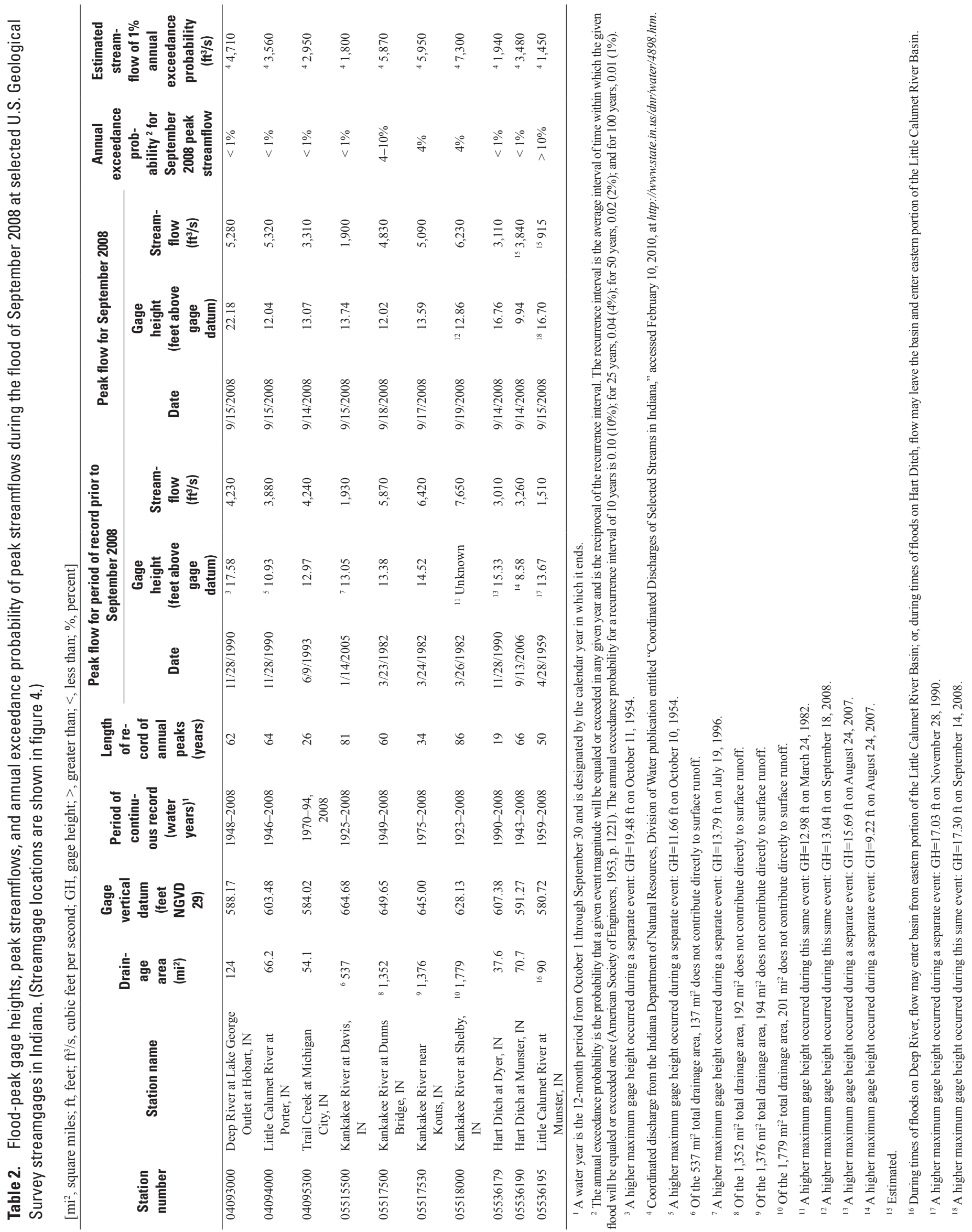




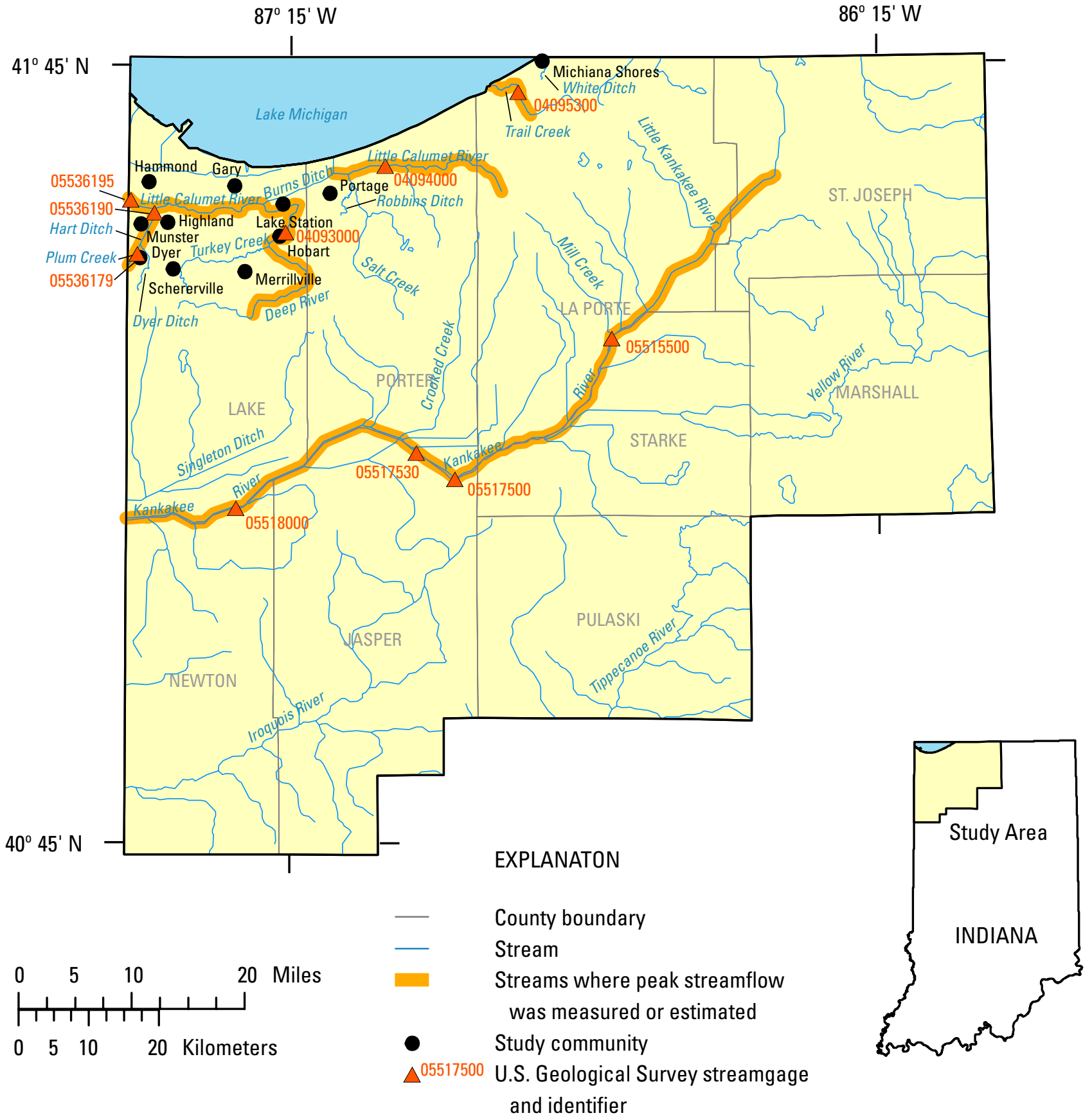

Figure 4. Locations of selected U.S. Geological Survey streamgages. (See table 2 for flood-related data.) 


\section{Estimation of Annual Exceedance Probabilities}

Annual exceedance probabilities (the reciprocal of the recurrence intervals) associated with the peak streamflows for 10 active streamgages (table 2 ) were estimated to indicate the relative magnitude of the September 2008 flooding. Annual exceedance probabilities were obtained from "coordinated" discharge-frequency curves available in the IDNR online publication "Coordinated Discharges of Selected Streams in Indiana" (http://www.in.gov/dnr/water/4898.htm). The methods used to produce the flood discharge-frequency curves are outlined in Bulletin 17B, the "Guidelines for Determining Flood Flow Frequency" (U.S. Interagency Advisory Committee on Water Data, 1982). The coordinated discharge-frequency curves were established and are maintained according to a Memorandum of Understanding dated May 6, 1976, that was signed by the U.S. Department of Agriculture, Soil Conservation Service (now the Natural Resources Conservation Service), the USGS, the U.S. Army Corps of Engineers, and the IDNR. These agencies agreed to coordinate dischargefrequency values for use in water-resources investigations and planning activities in Indiana.

\section{Estimated Magnitudes and Annual Exceedance Probabilities of Peak Streamflows for the Flood of September 2008}

Peak-gage-height data, peak-streamflow data, and estimated annual exceedance probabilities from the September flood for 10 USGS streamgages in northwestern Indiana are listed in table 2, and streamgage locations are shown in figure 4. New streamflow peaks of record were set at 4 of the 10 streamgages. For the 10 streamgages, the estimated annual exceedance probabilities were less than 0.01 ( 1 percent) for 6 streamgages, 0.04 (4 percent) at 2 streamgages, between 0.04 (4 percent) and 0.1 (10 percent) at 1 streamgage, and greater than 0.1 (10 percent) at 1 streamgage. In terms of recurrence intervals for the 10 streamgages, estimated recurrence intervals were greater than 100 years at 6 streamgages, 25 years at 2 streamgages, $10-25$ years at 1 streamgage, and less than 10 years at 1 streamgage.

\section{Flood-Peak Inundation Maps}

Flood-peak inundation maps were produced for four stream reaches in the study area (fig. 4) by use of geographic information system (GIS) software and programs. High-watermark elevations (NAVD 88) and locations (latitude-longitude) were used in conjunction with GIS land-surface elevation data files, termed "digital elevation models" (DEMs), to develop the maps. For study reaches that included a streamgage, the peak gage height recorded by the streamgage also was used to develop the maps. GIS Arc Macro Language (AML) programs were written to produce a plane representing the flood-peak water surface that was fit through the high-water marks and that sloped in the direction of water flow. The program duplicated the high-water-mark elevation data points across the flood plain perpendicular to the direction of the flood flow. Elevations between high-water marks are proportional interpolations of the high-water-mark data and are positioned to generate a flood surface sloping with the water flow. A TIN (triangular irregular network) surface was fit through the data points (TIN-generated surfaces pass exactly through the data-point elevations). After the flood surface was generated, a flood-depth map was made by subtracting the DEM from the flood surface. The flood-peak inundation maps were produced in a GIS file format that provides peak flood extent and depth. This format allows the maps to be overlain upon other maps and aerial photographs and to be imported into various GIS applications, such as FEMA's HAZUS-MH program (Federal Emergency Management Agency, 2008b) to estimate flood damages. Selected flood-map illustrations created from the peak flood extent and depth GIS files and from aerial photographs are presented in appendix 2. In the cases of Hart Ditch and Dyer Ditch, inundation maps were not developed because of inaccuracies in the DEM data and because of credible local reports that the floodwaters generally did not overtop the constructed boundaries of the drainage channel. An inundation map was not produced for Robbins Ditch, also because of DEM data inaccuracies.

\section{Flood-Peak Profiles}

The AML programs used to produce flood-peak maps were developed further to generate flood-peak profile plots. Flood profiles were produced for seven streams in the study area (appendix 3). The profiles were produced by plotting high-water-mark elevations (NAVD 88) by mile of stream as measured upstream from the mouth of the stream. The water surface between high-water marks was estimated by linear interpolation. A linear interpolation between high-water marks is an approximation of the actual water surface, which may have departed substantially from the water surface depicted in the profiles in some locations. For example, it is common for the water surface to drop between the upstream and downstream face of a bridge or culvert; potential water-surface elevation drops may not be reflected in the profiles. Locations of street crossings over the streams were added to the plots in another software package. The river-mile location of the street crossings was calculated by GIS-based programs. 


\section{Description of Flood Damages and Impacts}

Record flooding, power outages, and evacuations affected thousands of northwestern Indiana residents during September 2008 and caused millions of dollars worth of damage to homes, businesses, and infrastructure. Areas of flooding were extensive in the communities of Munster, Dyer, Hobart, Portage, and Michiana Shores as local streams and ditches rose rapidly during September 12-15, 2008. Hart Ditch at Dyer and Hart Ditch at Munster both peaked on September 14 at stages and discharges that exceeded the previous records. Trail Creek at Michigan City and Little Calumet River at Munster also peaked on September 14, both at record stage. Little Calumet River at Porter, Deep River at Lake George Outlet, and the Kankakee River at Davis continued rising and peaked the following day, September 15. Both Deep River and the Little Calumet River (at Porter) exceeded previous record stage and discharge. Stream reaches further downstream on the Kankakee River peaked from September 17 to 19.

The following is a summary of flood impacts compiled after September 2008:

- The flooding caused two fatalities and numerous injuries.

- More than 5,000 evacuations and water rescues were made during the flooding (Shipe, 2008).

- About 180 Indiana National Guard Soldiers and Airmen supported relief missions during flooding in northern Indiana.

- Food and drinking-water distribution points were set up in the affected counties.

- Levee breaches occurred in Lake and Newton Counties.

- Main electric transmission lines were damaged.

- Emergency Services Radio Towers were damaged by wind.

- Transportation disruptions were widespread. A 40-mile stretch of Interstate 65 was closed for 2 days (Midwest Regional Climate Center, 2008).

- Runoff from tributaries carried massive amounts of sediment into Lake Michigan, contaminating the water, compromising nearshore navigation, and raising Escherichia coli bacteria concentrations to levels unsafe for swimming (Whitman, 2008).
- State disaster centers helped nearly 25,000 people in Lake, Porter, and La Porte Counties whose lives were disrupted by the severe weather. The centers were open from September 25 to October 1 and included 300 Family and Social Services Administration (FSSA) employees, who took 24,137 applications for emergency food stamps; additionally, FSSA's Division of Mental Health and Addiction deployed 13 crisis counselors to provide counseling services to more than 2,600 residents. The Indiana Department of Insurance and Indiana Department of Workforce Development each assisted several hundred people with questions about insurance policies or employment. The State's Office of Information Technology set up hundreds of computers at six centers to aid storm victims making applications for assistance. The Indiana Housing and Community Development Authority provided temporary housing for more than 250 families (Indiana Office of Disaster Recovery, 2008).

On September 23, 2008, President George W. Bush declared that a major disaster existed in northwestern Indiana, and that declaration cleared the way for assistance for residents and businesses. As of February 2009, a total of 26,047 homeowners, renters, and business owners had applied for disaster assistance from FEMA. Grants and loans were approved for $\$ 78,554,288$, which included $\$ 28,519,988$ in housing assistance, $\$ 5,761,698$ in other needs assistance (ONA), and $\$ 28,774,500$ in U.S. Small Business Administration disaster loans (Federal Emergency Management Agency, 2008c).

\section{Summary}

Heavy rains resulted in severe flooding on September 12-18, 2008, and caused millions of dollars worth of damage to homes, businesses, and infrastructure in northwestern Indiana. Two deaths were attributed to the flooding, and thousands of persons were evacuated from flooded areas.

Estimated rainfall totals ranging from 2 to more than 11 inches fell during September 12-15 upon saturated soils and caused record streamflows. Average recurrence intervals of total rainfall amounts for a 4-day duration ranged from greater than 100 years to greater than 500 years at six NWS precipitation stations. Given the severity of the September 2008 flooding in Indiana, the USGS, in cooperation with the FEMA and the IDNR, Division of Water, completed this study to document the meteorological and hydrological conditions leading to the flood; compile flood-peak gage heights, streamflows, and annual exceedance probabilities at selected USGS streamgages; construct flood profiles and peak-gage-height inundation maps; and summarize flood damages and impacts. 


\section{References Cited}

American Society of Civil Engineers, 1953, Report of the subcommittee on the joint division committee on floods: American Society of Civil Engineers Transactions, v. 118, p.1220-1230.

Bonnin, G.M.; Martin, Deborah; Lin, Bingzhang; Parzybok, Tye; Yekta, Michael; and Riley, David, 2006, Precipitationfrequency atlas of the United States: National Oceanic and Atmospheric Administration Atlas 14, v. 2, ver. 3.0 [variously paged], accessed April 5, 2010, at http://www.weather. gov/oh/hdsc/PF_documents/Atlas14_Volume2.pdf.

Federal Emergency Management Agency, 2008a, 2008 Federal disaster declarations: Accessed March 29, 2010, at http:// www.fema.gov/news/disasters.fema.

Federal Emergency Management Agency, 2008b, HAZUS: Accessed October 7, 2008, at http://www.fema.gov/plan/ prevent/hazus/.

Federal Emergency Management Agency, 2008c, Federal Assistance for Indiana for Hurricane Ike tops \$78 million: Accessed April 2, 2010, at http://www.fema.gov/news/ newsrelease. fema? $i d=47493$.

Hodgkins, G.A., Stewart, G.J., Cohn, T.A., and Dudley, R.W., 2007, Estimated magnitudes and recurrence intervals of peak flows on the Mousam and Little Ossipee Rivers for the flood of April 2007 in southern Maine: U.S. Geological Survey Open-File Report 2007-1146, 5 p., accessed August 12, 2009, at http://pubs.usgs.gov/of/2007/1146/.

Indiana Department of Natural Resources [n.d.], Coordinated discharges of selected streams in Indiana: Accessed February 10, 2010, at http://www.in.gov/dnr/water/4898.htm.

Indiana Office of Disaster Recovery, September 2008 flood: Accessed June 12, 2009, at http://www.in.gov/gov/odr.htm.

Indiana State Climate Office, 2008a, August 2008 climate summary: 12 p. (Also available at http://climate.agry. purdue.edu/climate/summary/2008-08.pdf.)

Indiana State Climate Office, 2008b, September 2008 cli-

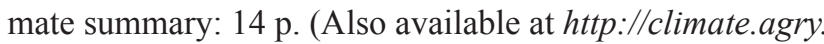
purdue.edu/climate/summary/2008-09.pdf.)

Langbein, W.B., and Iseri, K.T., 1960, General introduction and hydrologic definitions, Manual of Hydrology. Part 1, General surface-water techniques: U.S. Geological Survey Water-Supply Paper 1541-A, 29 p., accessed September 6, 2008, at http://pubs.er.usgs.gov/usgspubs/wsp/wsp1541A.
Lumia, Richard; Burke, P.M.; and Johnston, W.H., 1986, Flooding of December 29, 1984, through January 2, 1985, in northern New York State, with flood profiles of the Black and Salmon Rivers: U.S. Geological Survey WaterResources Investigations Report 86-4191, 53 p.

Midwest Regional Climate Center, Midwest Climate Watch, 2008, Midwest highlights, September 2008: Accessed March 4, 2010, at http://mrcc.isws.illinois.edu/ cliwatch/0809/080916.htm.

Morlock, S.E., Menke, C.D., Arvin, D.V., and Kim, M.H., 2008, Flood of June 7-9, 2008, in central and southern Indiana: U.S. Geological Survey Open File Report 2008-1322, 15 p., 3 app.

National Climatic Data Center, Midwestern U.S. flood overview: Accessed March 4, 2010, at http://www.ncdc.noaa. gov/sotc/?report $=$ national\&year $=2008 \&$ month $=9 \&$ submitt ed $=$ Get + Report .

National Oceanic and Atmospheric Administration, 2008a, Climatological Data, Indiana, September 2008, Vol. 113, Number 09, ISSN 0145-053, 26 p.

National Oceanic and Atmospheric Administration, 2008b, NCDC NEXRAD data inventory, 2008: Accessed September 15, 2009, at http://www.ncdc.noaa.gov/oa/radar/ radardata.html.

National Weather Service, 2005, National Weather Service glossary: Accessed September 22, 2008, at $h t t p: / / w w w$. weather.gov/glossary/.

Rantz, S.E., and others, 1982, Measurement and computation of streamflow-Volume 1, Measurement of stage and discharge, and volume 2, Computation of discharge: U.S. Geological Survey Water-Supply Paper 2175, 631 p.

Sherwood, J.M., Ebner, A.E., Koltun, G.F., and Astifan, B.N., 2007, Flood of June 22-24, 2006, in north-central Ohio, with emphasis on the Cuyahoga River near Independence: U.S. Geological Survey Scientific Investigations Report 2007-5161, 18 p., accessed August 12, 2009, at http://pubs. usgs.gov/sir/2007/5161/.

Shipe, A.P., 2008, National Weather Service monthly report of river and flood conditions for Indiana: September 2008, 2 p.

U.S. Interagency Advisory Committee on Water Data, 1982, Guidelines for determining flood flow frequency, Bulletin 17-B of the Hydrology Subcommittee: Reston, Virginia, U.S. Geological Survey, Office of Water Data Coordination, [183 p.].

Whitman, R.L., 2008, Hurricane Ike's effects linger in the Great Lakes: U.S. Geological Survey Newsroom article, accessed March 30, 2010, at http://www.usgs.gov/ newsroom/article.asp? $I D=2030$. 


\section{Glossary}

The following definitions, except where noted, are from Langbein and Iseri (1960).

annual exceedance probability The probability that a given event magnitude will be exceeded or equaled in any given year. For example, the annual exceedance probability of the 100 -year peak flood streamflow is 0.01 . In other words, there is a 1-percent chance that the 100 -year peak flow will be exceeded or equaled in any given year.

cold front A zone separating two air masses, of which the cooler, denser mass is advancing and replacing the warmer (National Weather Service, 2005).

cubic feet per second A unit expressing rates of discharge. One cubic foot per second is equal to the discharge of a stream of rectangular cross section, 1 foot wide and 1 foot deep, flowing water an average velocity of 1 foot per second.

flood peak The highest value of the stage or discharge attained by a flood; thus, peak stage or peak discharge. "Flood crest" has nearly the same meaning, but since it connotes the top of the flood wave, it is properly used only in referring to stage- thus, "crest stage," but not "crest discharge."

flood plain A strip of relatively smooth land bordering a stream, built of sediment carried by the stream and dropped in the slack water beyond the influence of the swiftest current. It is called a living flood plain if it is overflowed in times of highwater, but a fossil flood plain if it is beyond the reach of the highest flood.

flood profile A graph of elevation of the water surface of a river in flood, plotted as ordinate, against distance, measured in the downstream direction, plotted as abscissa. A flood profile may be drawn to show elevation at a given time or crests during a particular flood.

gage height The water-surface elevation referred to some arbitrary gage datum. Gage height is often used interchangeably with the more general term "stage," although gage height is more appropriate when used with a reading on a gage.

recurrence interval (return period) The average interval of time within which the given flood will be equaled or exceeded once.

stream A general term for a body of flowing water. In hydrology the term is generally applied to the water flowing in a natural channel as distinct from a canal. streamflow The discharge that occurs in a natural channel. Although the term "discharge" can be applied to the flow of a canal, the word "streamflow" uniquely describes the discharge in a surface stream course.

streamgage A gaging station where a record of discharge of a stream is obtained. Within the U.S. Geological Survey this term is used only for those gaging stations where a continuous record of gage-height is obtained. 


\section{Appendix 1. Site Descriptions and High-Water Marks at Study Sites, Flood of September 2008, Indiana.}

[Vertical coordinate data are referenced to the North American Vertical Datum of 1988 (NAVD 88). Horizontal coordinate data are referenced to the North American Datum of 1983. Approximate quantitative indications of accuracy of high-water-mark ratings: Excellent, \pm 0.02 foot; Good, \pm 0.05 foot; Fair, \pm 0.10 foot; and Poor, $>0.10$ foot (Lumia and others ,1986); for bank of nearest watercourse, "right" and "left" refer to an observation looking in the downstream direction of the watercourse. RM, reference mark]

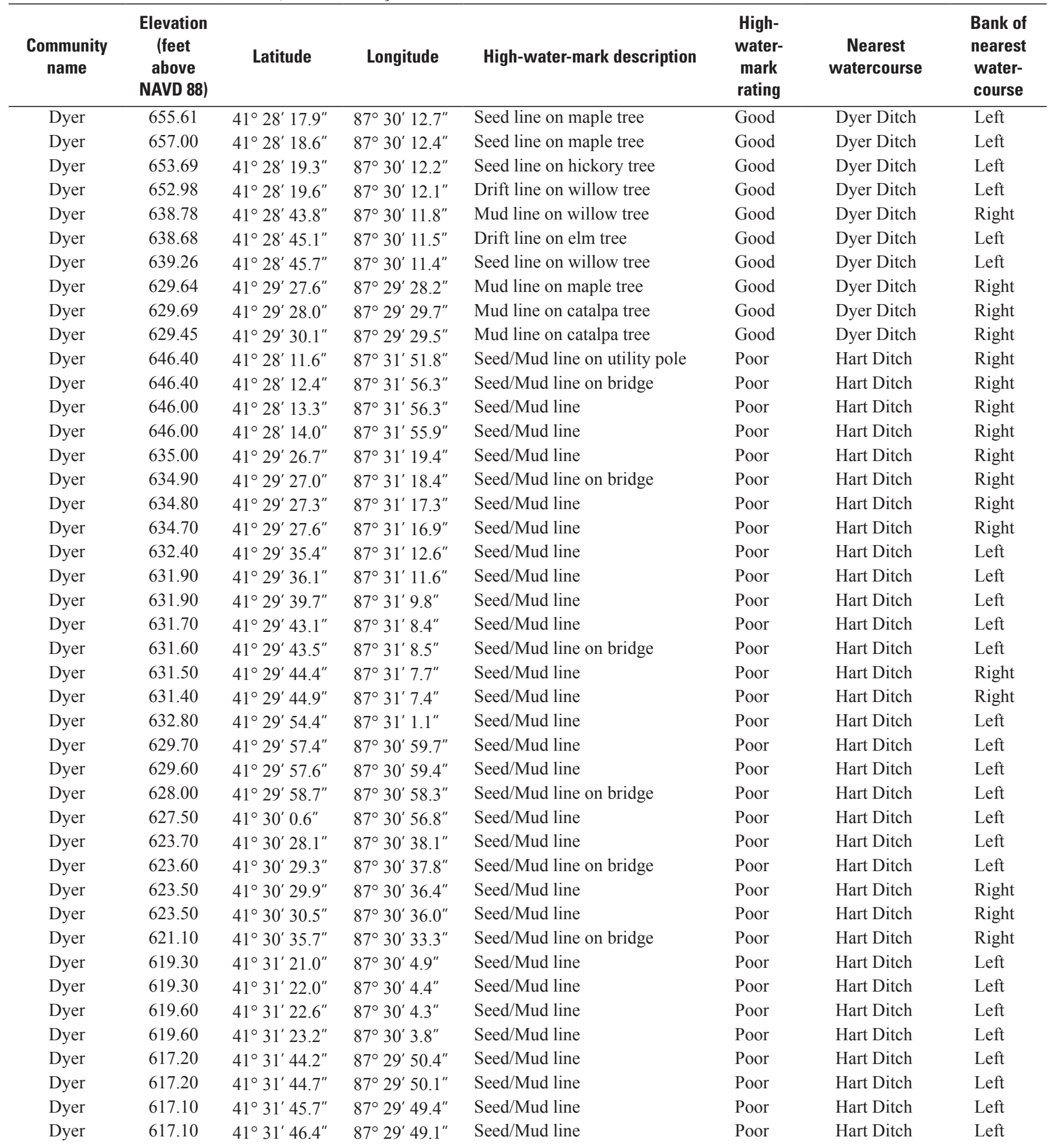


[Vertical coordinate data are referenced to the North American Vertical Datum of 1988 (NAVD 88). Horizontal coordinate data are referenced to the North American Datum of 1983. Approximate quantitative indications of accuracy of high-water-mark ratings: Excellent, \pm 0.02 foot; Good, \pm 0.05 foot; Fair, \pm 0.10 foot; and Poor, $>0.10$ foot (Lumia and others , 1986); for bank of nearest watercourse, "right" and "left" refer to an observation looking in the downstream direction of the watercourse. RM, reference mark]

\begin{tabular}{|c|c|c|c|c|c|c|c|}
\hline $\begin{array}{c}\text { Community } \\
\text { name }\end{array}$ & $\begin{array}{c}\text { Elevation } \\
\text { (feet } \\
\text { above } \\
\text { NAVD 88) }\end{array}$ & Latitude & Longitude & High-water-mark description & $\begin{array}{l}\text { High- } \\
\text { water- } \\
\text { mark } \\
\text { rating }\end{array}$ & $\begin{array}{c}\text { Nearest } \\
\text { watercourse }\end{array}$ & $\begin{array}{c}\text { Bank of } \\
\text { nearest } \\
\text { water- } \\
\text { course }\end{array}$ \\
\hline Gary & 598.97 & $41^{\circ} 34^{\prime} 22.5^{\prime \prime}$ & $87^{\circ} 19^{\prime} 19.7^{\prime \prime}$ & $\begin{array}{l}\text { Tape up from water surface to } \\
\text { levee }\end{array}$ & Poor & Little Calumet & Left \\
\hline Gary & 596.99 & $41^{\circ} 34^{\prime} 19.8^{\prime \prime}$ & $87^{\circ} 19^{\prime} 12.4^{\prime \prime}$ & Mud line on tree & Fair & Little Calumet & Right \\
\hline Highland & 616.50 & $41^{\circ} 31^{\prime} 49.8^{\prime \prime}$ & $87^{\circ} 29^{\prime} 45.8^{\prime \prime}$ & Seed/Mud line & Poor & Hart Ditch & Right \\
\hline Highland & 616.30 & $41^{\circ} 31^{\prime} 50.2^{\prime \prime}$ & $87^{\circ} 29^{\prime} 45.3^{\prime \prime}$ & Seed/Mud line & Poor & Hart Ditch & Right \\
\hline Highland & 615.70 & $41^{\circ} 31^{\prime} 52.1^{\prime \prime}$ & $87^{\circ} 29^{\prime} 45.4^{\prime \prime}$ & Seed/Mud line & Poor & Hart Ditch & Left \\
\hline Highland & 615.70 & $41^{\circ} 31^{\prime} 52.5^{\prime \prime}$ & $87^{\circ} 29^{\prime} 45.3^{\prime \prime}$ & Seed/Mud line & Poor & Hart Ditch & Left \\
\hline Highland & 613.70 & $41^{\circ} 32^{\prime} 12.0^{\prime \prime}$ & $87^{\circ} 29^{\prime} 33.4^{\prime \prime}$ & Seed/Mud line & Poor & Hart Ditch & Left \\
\hline Highland & 613.70 & $41^{\circ} 32^{\prime} 12.7^{\prime \prime}$ & $87^{\circ} 29^{\prime} 33.2^{\prime \prime}$ & Seed/Mud line & Poor & Hart Ditch & Left \\
\hline Highland & 610.70 & $41^{\circ} 32^{\prime} 34.8^{\prime \prime}$ & $87^{\circ} 29^{\prime} 18.9^{\prime \prime}$ & Seed/Mud line & Poor & Hart Ditch & Left \\
\hline Highland & 610.40 & $41^{\circ} 32^{\prime} 37.1^{\prime \prime}$ & $87^{\circ} 29^{\prime} 17.2^{\prime \prime}$ & Seed/Mud line & Poor & Hart Ditch & Left \\
\hline Highland & 610.30 & $41^{\circ} 32^{\prime} 37.5^{\prime \prime}$ & $87^{\circ} 29^{\prime} 16.9^{\prime \prime}$ & Seed/Mud line & Poor & Hart Ditch & Left \\
\hline Highland & 603.00 & $41^{\circ} 32^{\prime} 25.0^{\prime \prime}$ & $87^{\circ} 28^{\prime} 52.1^{\prime \prime}$ & Seed/Mud line & Poor & Hart Ditch & Left \\
\hline Highland & 603.10 & $41^{\circ} 33^{\prime} 25.5^{\prime \prime}$ & $87^{\circ} 28^{\prime} 52.3^{\prime \prime}$ & Seed/Mud line & Poor & Hart Ditch & Left \\
\hline Highland & 603.20 & $41^{\circ} 33^{\prime} 27.2^{\prime \prime}$ & $87^{\circ} 28^{\prime} 51.9^{\prime \prime}$ & Seed/Mud line & Poor & Hart Ditch & Left \\
\hline Highland & 603.00 & $41^{\circ} 33^{\prime} 27.7^{\prime \prime}$ & $87^{\circ} 28^{\prime} 51.8^{\prime \prime}$ & Seed/Mud line & Poor & Hart Ditch & Left \\
\hline Highland & 598.72 & $41^{\circ} 33^{\prime} 37.2^{\prime \prime}$ & $87^{\circ} 23^{\prime} 37.0^{\prime \prime}$ & Seed/Mud line on elm tree & Good & Little Calumet & Right \\
\hline Highland & 598.79 & $41^{\circ} 33^{\prime} 35.3^{\prime \prime}$ & $87^{\circ} 23^{\prime} 37.6^{\prime \prime}$ & Seed/Drift line on bridge & Good & Little Calumet & Right \\
\hline Highland & 599.07 & $41^{\circ} 33^{\prime} 34.3^{\prime \prime}$ & $87^{\circ} 23^{\prime} 38.1^{\prime \prime}$ & Seed/Drift line & Good & Little Calumet & Right \\
\hline Highland & 599.11 & $41^{\circ} 34^{\prime} 10.9^{\prime \prime}$ & $87^{\circ} 27^{\prime} 42.3^{\prime \prime}$ & Mud/Seed line on bridge & Good & Little Calumet & Right \\
\hline Highland & 598.96 & $41^{\circ} 34^{\prime} 9.9^{\prime \prime}$ & $87^{\circ} 27^{\prime} 59.9^{\prime \prime}$ & Mud/Seed line on bridge & Good & Little Calumet & Left \\
\hline Highland & 599.16 & $41^{\circ} 34^{\prime} 11.1^{\prime \prime}$ & $87^{\circ} 28^{\prime} 0.3^{\prime \prime}$ & Mud/Seed line on bridge & Good & Little Calumet & Right \\
\hline Highland & 600.17 & $41^{\circ} 34^{\prime} 6.8^{\prime \prime}$ & $87^{\circ} 28^{\prime} 27.7^{\prime \prime}$ & Mud/Seed line on boxelder tree & Good & Little Calumet & Right \\
\hline Highland & 599.57 & $41^{\circ} 34^{\prime} 6.0^{\prime \prime}$ & $87^{\circ} 28^{\prime} 29.8^{\prime \prime}$ & Seed/Drift line on bridge & Good & Little Calumet & Right \\
\hline Highland & 597.72 & $41^{\circ} 33^{\prime} 58.3^{\prime \prime}$ & $87^{\circ} 29^{\prime} 6.0^{\prime \prime}$ & Mud line on utilty pole & Good & Little Calumet & Left \\
\hline Highland & 597.71 & $41^{\circ} 33^{\prime} 58.4^{\prime \prime}$ & $87^{\circ} 29^{\prime} 8.0^{\prime \prime}$ & Mud line on utilty pole & Good & Little Calumet & Left \\
\hline Highland & 600.62 & $41^{\circ} 33^{\prime} 58.7^{\prime \prime}$ & $87^{\circ} 29^{\prime} 11.8^{\prime \prime}$ & $\mathrm{Mud} /$ Seed line on ash tree & Good & Little Calumet & Left \\
\hline Hobart & 610.95 & $41^{\circ} 32^{\prime} 5.6^{\prime \prime}$ & $87^{\circ} 15^{\prime} 28.3^{\prime \prime}$ & Seed line on cottonwood tree & Fair & Deep River & Left \\
\hline Hobart & 610.00 & $41^{\circ} 32^{\prime} 8.3^{\prime \prime}$ & $87^{\circ} 15^{\prime} 26.6^{\prime \prime}$ & Seed line on ash tree & Good & Deep River & Left \\
\hline Hobart & 609.93 & $41^{\circ} 32^{\prime} 6.1^{\prime \prime}$ & $87^{\circ} 15^{\prime} 28.2^{\prime \prime}$ & Seed line on bridge & Good & Deep River & Left \\
\hline Hobart & 609.99 & $41^{\circ} 32^{\prime} 12.9^{\prime \prime}$ & $87^{\circ} 15^{\prime} 20.5^{\prime \prime}$ & Mud line on ash tree & Good & Deep River & Left \\
\hline Hobart & 606.42 & $41^{\circ} 32^{\prime} 13.4^{\prime \prime}$ & $87^{\circ} 15^{\prime} 19.2^{\prime \prime}$ & Seed line on sassafrass tree & Good & Deep River & Left \\
\hline Hobart & 605.58 & $41^{\circ} 32^{\prime} 49.4^{\prime \prime}$ & $87^{\circ} 14^{\prime} 54.2^{\prime \prime}$ & Seed line on guardrail & Good & Deep River & Right \\
\hline Hobart & 605.13 & $41^{\circ} 32^{\prime} 49.6^{\prime \prime}$ & $87^{\circ} 14^{\prime} 57^{\prime \prime}$ & Seed line on concrete wingwall & Good & Deep River & Left \\
\hline Hobart & 604.65 & $41^{\circ} 33^{\prime} 1.5^{\prime \prime}$ & $87^{\circ} 15^{\prime} 9.1^{\prime \prime}$ & Mud line on mulberry tree & Good & Deep River & Left \\
\hline Hobart & 604.65 & $41^{\circ} 33^{\prime} 1.8^{\prime \prime}$ & $87^{\circ} 15^{\prime} 9.1^{\prime \prime}$ & Seed line on cottonwood tree & Good & Deep River & Left \\
\hline Hobart & 604.11 & $41^{\circ} 33^{\prime} 4.1^{\prime \prime}$ & $87^{\circ} 15^{\prime} 8.5^{\prime \prime}$ & Mud line on bridge & Good & Deep River & Left \\
\hline
\end{tabular}


[Vertical coordinate data are referenced to the North American Vertical Datum of 1988 (NAVD 88). Horizontal coordinate data are referenced to the North American Datum of 1983. Approximate quantitative indications of accuracy of high-water-mark ratings: Excellent, \pm 0.02 foot; Good, \pm 0.05 foot; Fair, \pm 0.10 foot; and Poor, $>0.10$ foot (Lumia and others , 1986); for bank of nearest watercourse, "right" and "left" refer to an observation looking in the downstream direction of the watercourse. RM, reference mark]

\begin{tabular}{|c|c|c|c|c|c|c|c|}
\hline $\begin{array}{c}\text { Community } \\
\text { name }\end{array}$ & $\begin{array}{c}\text { Elevation } \\
\text { (feet } \\
\text { above } \\
\text { NAVD 88) }\end{array}$ & Latitude & Longitude & High-water-mark description & $\begin{array}{c}\text { High- } \\
\text { water- } \\
\text { mark } \\
\text { rating }\end{array}$ & $\begin{array}{c}\text { Nearest } \\
\text { watercourse }\end{array}$ & $\begin{array}{c}\text { Bank of } \\
\text { nearest } \\
\text { water- } \\
\text { course }\end{array}$ \\
\hline Lake Station & 602.67 & $41^{\circ} 33^{\prime} 26.6^{\prime \prime}$ & $87^{\circ} 14^{\prime} 27.8^{\prime \prime}$ & Mud line on box elder & Good & Deep River & Right \\
\hline Lake Station & 602.73 & $41^{\circ} 33^{\prime} 27.2^{\prime \prime}$ & $87^{\circ} 14^{\prime} 25.1^{\prime \prime}$ & Mud line on cottonwood tree & Good & Deep River & Right \\
\hline Lake Station & 601.45 & $41^{\circ} 34^{\prime} 19.0^{\prime \prime}$ & $87^{\circ} 14^{\prime} 22.0^{\prime \prime}$ & Seed line on cottonwood tree & Good & Deep River & Left \\
\hline Lake Station & 601.42 & $41^{\circ} 34^{\prime} 18.1^{\prime \prime}$ & $87^{\circ} 14^{\prime} 23.4^{\prime \prime}$ & Seed line on locust tree & Good & Deep River & Right \\
\hline Lake Station & 601.38 & $41^{\circ} 34^{\prime} 17.4^{\prime \prime}$ & $87^{\circ} 14^{\prime} 28.4^{\prime \prime}$ & Mud line on tree & Good & Deep River & Right \\
\hline Merrillville & 614.83 & $41^{\circ} 30^{\prime} 40.5^{\prime \prime}$ & $87^{\circ} 18^{\prime} 28.8^{\prime \prime}$ & Seed line on basswood tree & Good & Turkey Creek & Right \\
\hline Merrillville & 614.79 & $41^{\circ} 30^{\prime} 41.4^{\prime \prime}$ & $87^{\circ} 18^{\prime} 27.4^{\prime \prime}$ & Seed line on ash tree & Good & Turkey Creek & Right \\
\hline Merrillville & 614.91 & $41^{\circ} 30^{\prime} 43.8^{\prime \prime}$ & $87^{\circ} 18^{\prime} 24.0^{\prime \prime}$ & Seed line on maple tree & Good & Turkey Creek & Right \\
\hline Merrillville & 615.63 & $41^{\circ} 30^{\prime} 37.9^{\prime \prime}$ & $87^{\circ} 19^{\prime} 15.0^{\prime \prime}$ & Mud line on oak tree & Good & Turkey Creek & Left \\
\hline Merrillville & 615.76 & $41^{\circ} 30^{\prime} 27.3^{\prime \prime}$ & $87^{\circ} 19^{\prime} 26.7^{\prime \prime}$ & Mud line on oak tree & Good & Turkey Creek & Left \\
\hline Merrillville & 615.93 & $41^{\circ} 30^{\prime} 27.1^{\prime \prime}$ & $87^{\circ} 19^{\prime} 26.9^{\prime \prime}$ & Seed line on birch tree & Good & Turkey Creek & Left \\
\hline Merrillville & 615.96 & $41^{\circ} 30^{\prime} 24.9^{\prime \prime}$ & $87^{\circ} 19^{\prime} 29.5^{\prime \prime}$ & Mud line on cottonwood tree & Good & Turkey Creek & Left \\
\hline Merrillville & 616.15 & $41^{\circ} 30^{\prime} 25.6^{\prime \prime}$ & $87^{\circ} 19^{\prime} 29.2^{\prime \prime}$ & Mud line on ash tree & Good & Turkey Creek & Left \\
\hline Merrillville & 617.11 & $41^{\circ} 30^{\prime} 16.0^{\prime \prime}$ & $87^{\circ} 20^{\prime} 0.5^{\prime \prime}$ & Seed line on oak tree & Good & Turkey Creek & Right \\
\hline Merrillville & 617.20 & $41^{\circ} 30^{\prime} 16.0^{\prime \prime}$ & $87^{\circ} 20^{\prime} 0.7^{\prime \prime}$ & Seed line on catalpa tree & Good & Turkey Creek & Right \\
\hline Merrillville & 617.61 & $41^{\circ} 30^{\prime} 15.9^{\prime \prime}$ & $87^{\circ} 20^{\prime} 12.7^{\prime \prime}$ & Drift line on utility pole & Good & Turkey Creek & Left \\
\hline Merrillville & 618.53 & $41^{\circ} 30^{\prime} 15.3^{\prime \prime}$ & $87^{\circ} 20^{\prime} 13.9^{\prime \prime}$ & Seed line on boxelder tree & Good & Turkey Creek & Left \\
\hline Merrillville & 620.14 & $41^{\circ} 30^{\prime} 8.6^{\prime \prime}$ & $87^{\circ} 20^{\prime} 40.7^{\prime \prime}$ & Mud line on walnut tree & Good & Turkey Creek & Right \\
\hline Merrillville & 621.79 & $41^{\circ} 29^{\prime} 57.9^{\prime \prime}$ & $87^{\circ} 21^{\prime} 54.9^{\prime \prime}$ & Seed line on utility pole & Good & Turkey Creek & Left \\
\hline Merrillville & 623.89 & $41^{\circ} 29^{\prime} 56.9^{\prime \prime}$ & $87^{\circ} 22^{\prime} 46.5^{\prime \prime}$ & Seed line on bridge & Good & Turkey Creek & Left \\
\hline Merrillville & 623.91 & $41^{\circ} 29^{\prime} 57.3^{\prime \prime}$ & $87^{\circ} 22^{\prime} 46.5^{\prime \prime}$ & Seed line on bridge & Good & Turkey Creek & Left \\
\hline $\begin{array}{r}\text { Michiana } \\
\text { Shores }\end{array}$ & 603.86 & $41^{\circ} 45^{\prime} 20.7^{\prime \prime}$ & $86^{\circ} 49^{\prime} 15.1^{\prime \prime}$ & Drift line on cherry tree & Fair & White Ditch & Right \\
\hline $\begin{array}{r}\text { Michiana } \\
\text { Shores }\end{array}$ & 603.82 & $41^{\circ} 45^{\prime} 21.8^{\prime \prime}$ & $86^{\circ} 49^{\prime} 13.6^{\prime \prime}$ & Drift line on boxelder tree & Fair & White Ditch & Right \\
\hline $\begin{array}{r}\text { Michiana } \\
\text { Shores }\end{array}$ & 602.87 & $41^{\circ} 45^{\prime} 23.3^{\prime \prime}$ & $86^{\circ} 49^{\prime} 12.8^{\prime \prime}$ & Seed line on silver maple tree & Fair & White Ditch & Left \\
\hline $\begin{array}{r}\text { Michiana } \\
\text { Shores }\end{array}$ & 603.29 & $41^{\circ} 45^{\prime} 23.7^{\prime \prime}$ & $86^{\circ} 49^{\prime} 12.3^{\prime \prime}$ & Seed line on silver maple tree & Fair & White Ditch & Left \\
\hline $\begin{array}{r}\text { Michiana } \\
\text { Shores }\end{array}$ & 602.90 & $41^{\circ} 45^{\prime} 29.8^{\prime \prime}$ & $86^{\circ} 49^{\prime} 0.5^{\prime \prime}$ & Mud line on cherry tree & Fair & White Ditch & Left \\
\hline $\begin{array}{r}\text { Michiana } \\
\text { Shores }\end{array}$ & 602.82 & $41^{\circ} 45^{\prime} 30.3^{\prime \prime}$ & $86^{\circ} 48^{\prime} 59.3^{\prime \prime}$ & Seed line on silver maple tree & Fair & White Ditch & Left \\
\hline $\begin{array}{r}\text { Michiana } \\
\text { Shores }\end{array}$ & 602.08 & $41^{\circ} 45^{\prime} 30.6^{\prime \prime}$ & $86^{\circ} 48^{\prime} 58.5^{\prime \prime}$ & Mud line on willow tree & Fair & White Ditch & Left \\
\hline $\begin{array}{r}\text { Michiana } \\
\text { Shores }\end{array}$ & 603.19 & $41^{\circ} 45^{\prime} 31.1^{\prime \prime}$ & $86^{\circ} 48^{\prime} 56.3^{\prime \prime}$ & Mud line on willow tree & Fair & White Ditch & Left \\
\hline Michiana & 602.16 & $41^{\circ} 45^{\prime} 31.8^{\prime \prime}$ & $86^{\circ} 48^{\prime} 52.0^{\prime \prime}$ & Mud line on elm tree & Poor & White Ditch & Right \\
\hline
\end{tabular}


[Vertical coordinate data are referenced to the North American Vertical Datum of 1988 (NAVD 88). Horizontal coordinate data are referenced to the North American Datum of 1983. Approximate quantitative indications of accuracy of high-water-mark ratings: Excellent, \pm 0.02 foot; Good, \pm 0.05 foot; Fair, \pm 0.10 foot; and Poor, $>0.10$ foot (Lumia and others , 1986); for bank of nearest watercourse, "right" and "left" refer to an observation looking in the downstream direction of the watercourse. RM, reference mark]

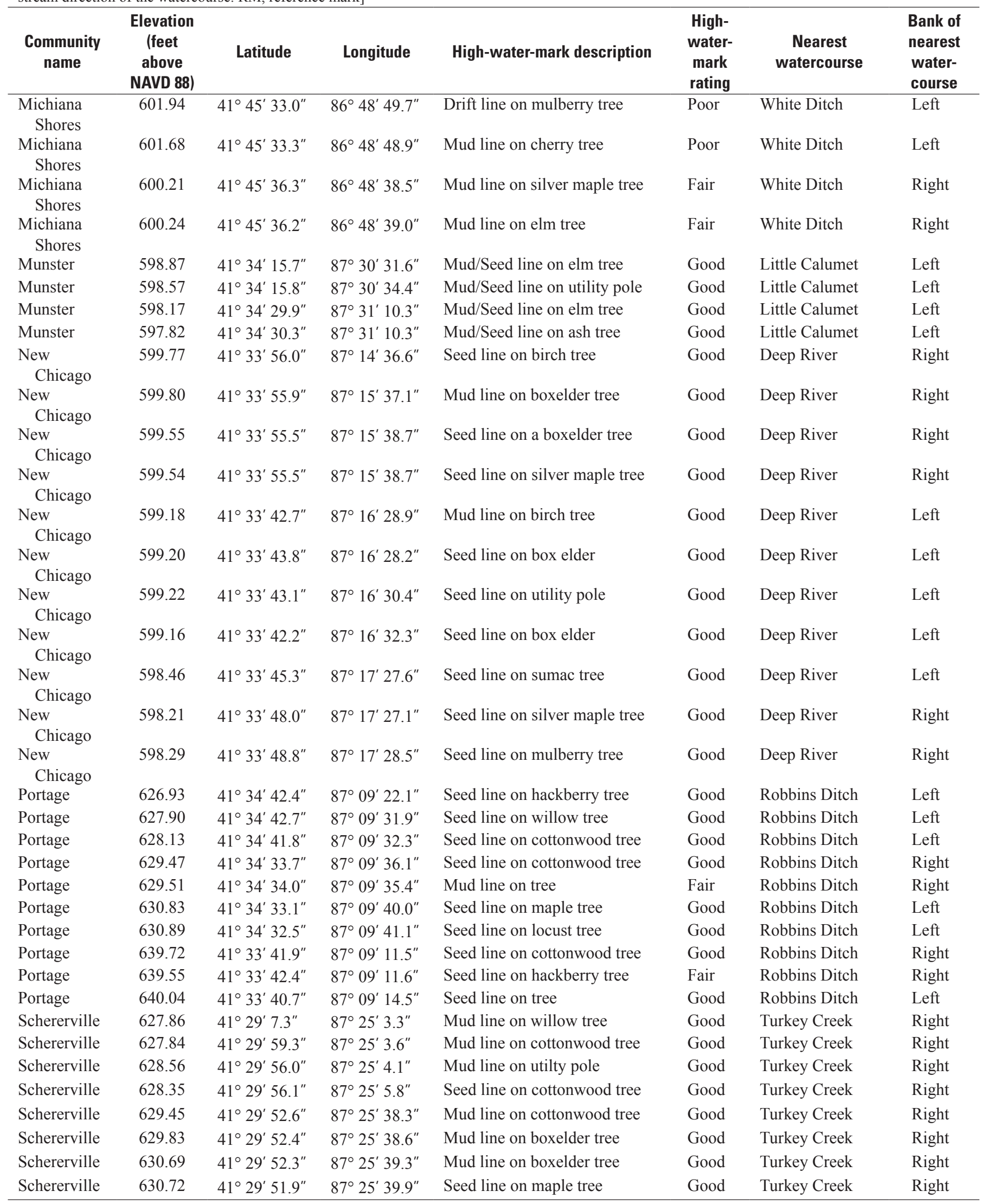




\section{Appendix 2. Flood-Peak Inundation Maps for Selected Study Streams and Communities, Flood of September 2008, Indiana.}

Appendix 2, which consists a series of maps showing approximate flood-peak inundation extents and depths, is available for downloading at

http://pubs.usgs.gov/ofr/2010/1098/

Streams and areas mapped are the following:

- Deep River near Hobart, Indiana.

- Little Calumet River near Highland, Ind.

- Little Calumet River near Munster, Ind.

- Turkey Creek near Schererville, Ind.

- White Ditch at Michiana Shores, Ind.

\section{Appendix 3. Flood-Peak Elevation Profiles for Selected Sites, Flood of September 2008, Indiana}

Water surfaces were estimated by linear interpolation between high-water marks. A linear interpolation between high-water marks is an approximation of the actual water surface; the actual water surface may have substantially departed from the water surface depicted in the profiles in some locations. For example, it is common for the water surface to drop between the upstream and downstream face of a bridge or culvert; potential water-surface elevation drops may not be reflected in the profiles. In some plots, a rise in the profile in the downstream direction can indicate a backwater condition caused by an obstruction. Water-surface elevations are referenced to the North American Vertical Datum of 1988 (NAVD 88). 


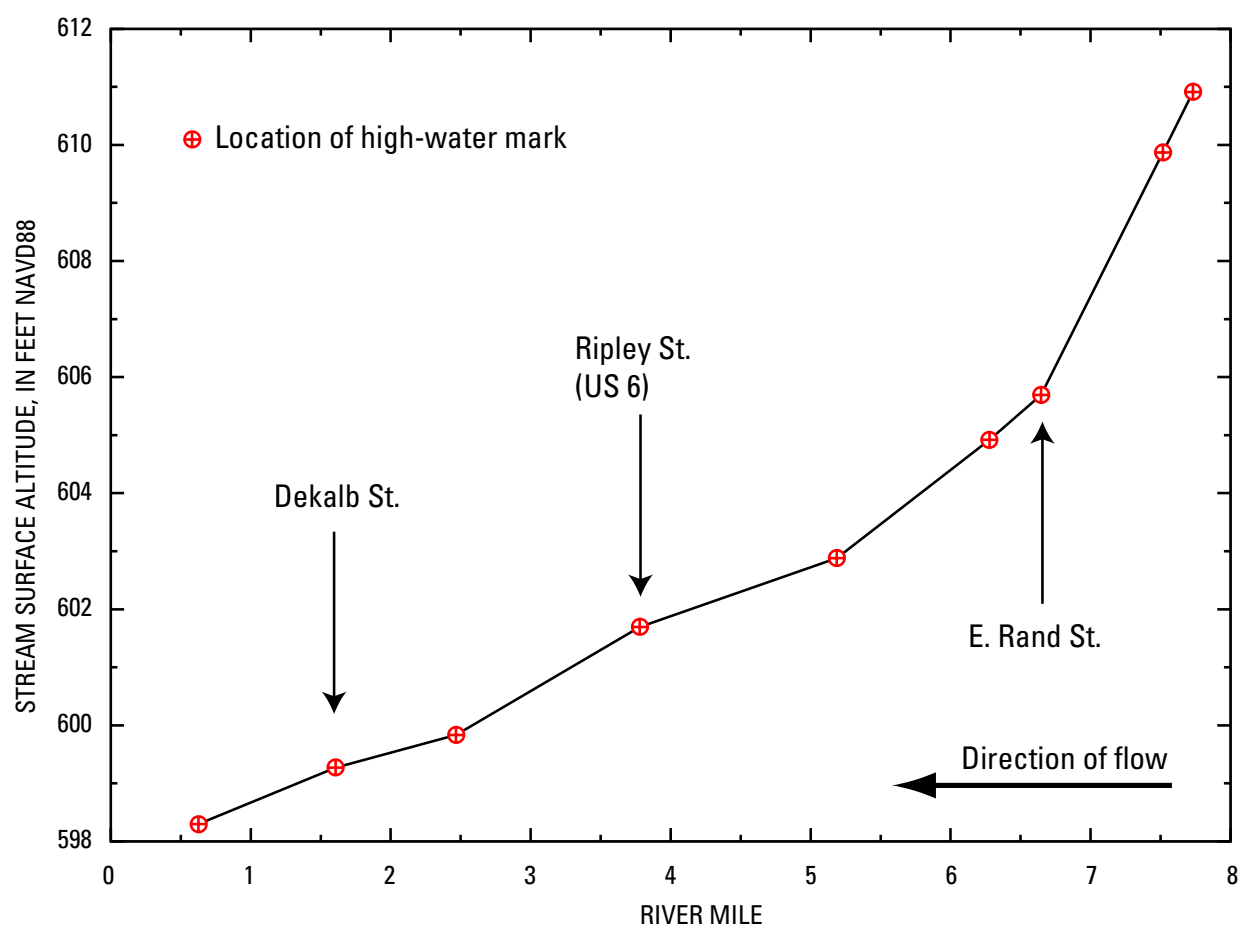

Flood-peak elevation profile, flood of September 2008, for Deep River near Hobart, Indiana.

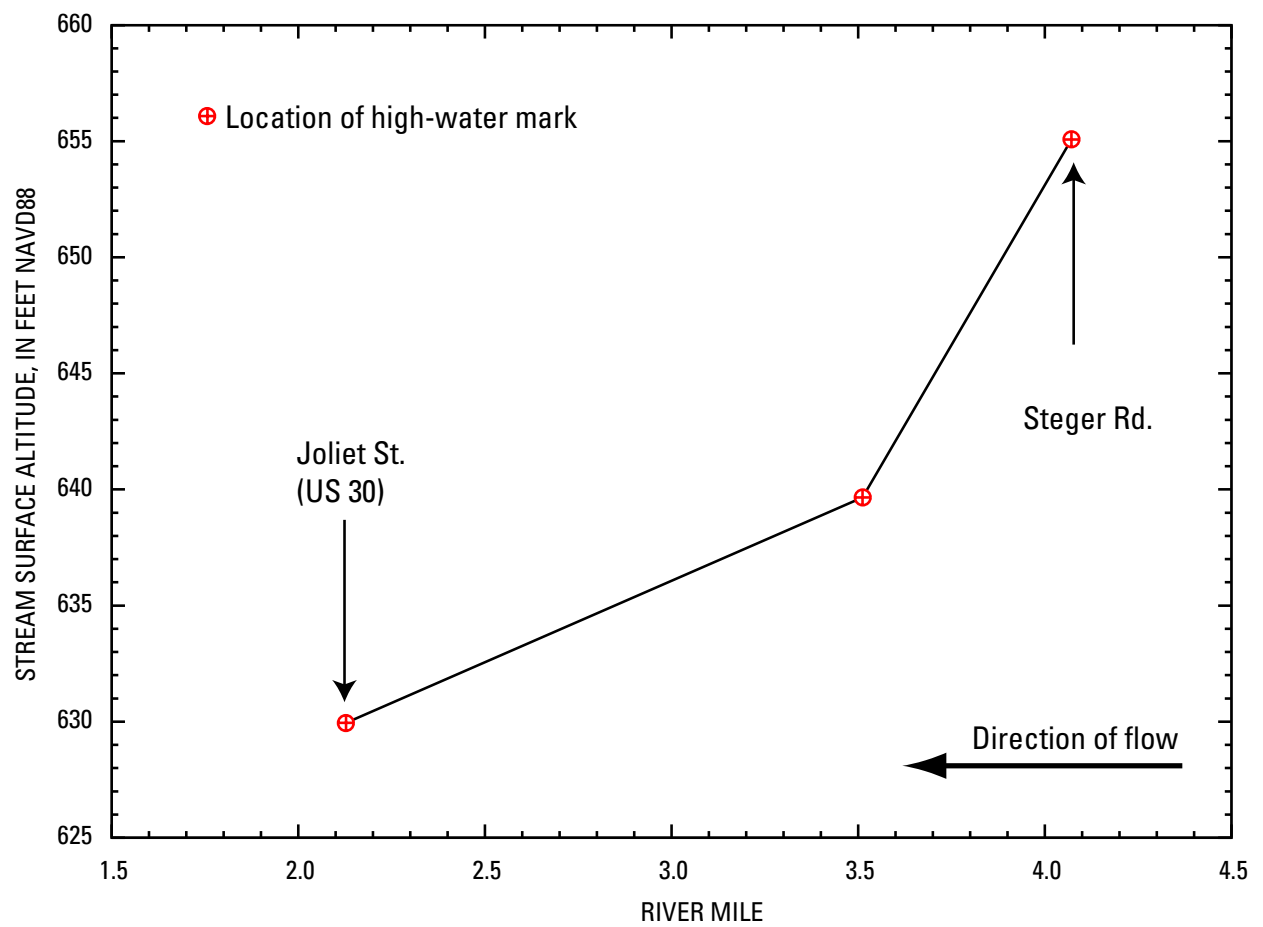

Flood-peak elevation profile, flood of September 2008, for Dyer Ditch at Dyer, Indiana. 


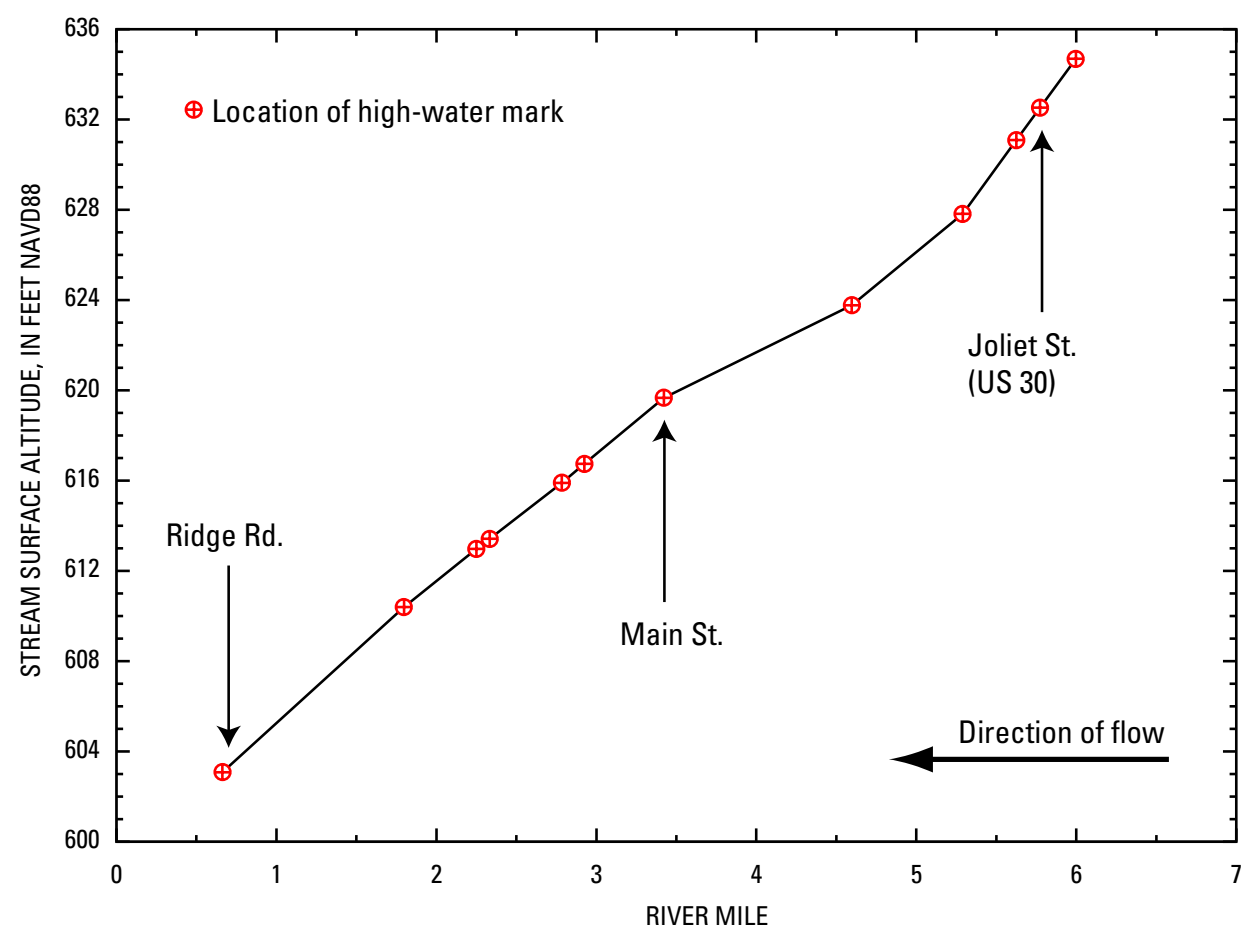

Flood-peak elevation profile, flood of September 2008, for Hart Ditch/Plum Creek near Dyer, Indiana.

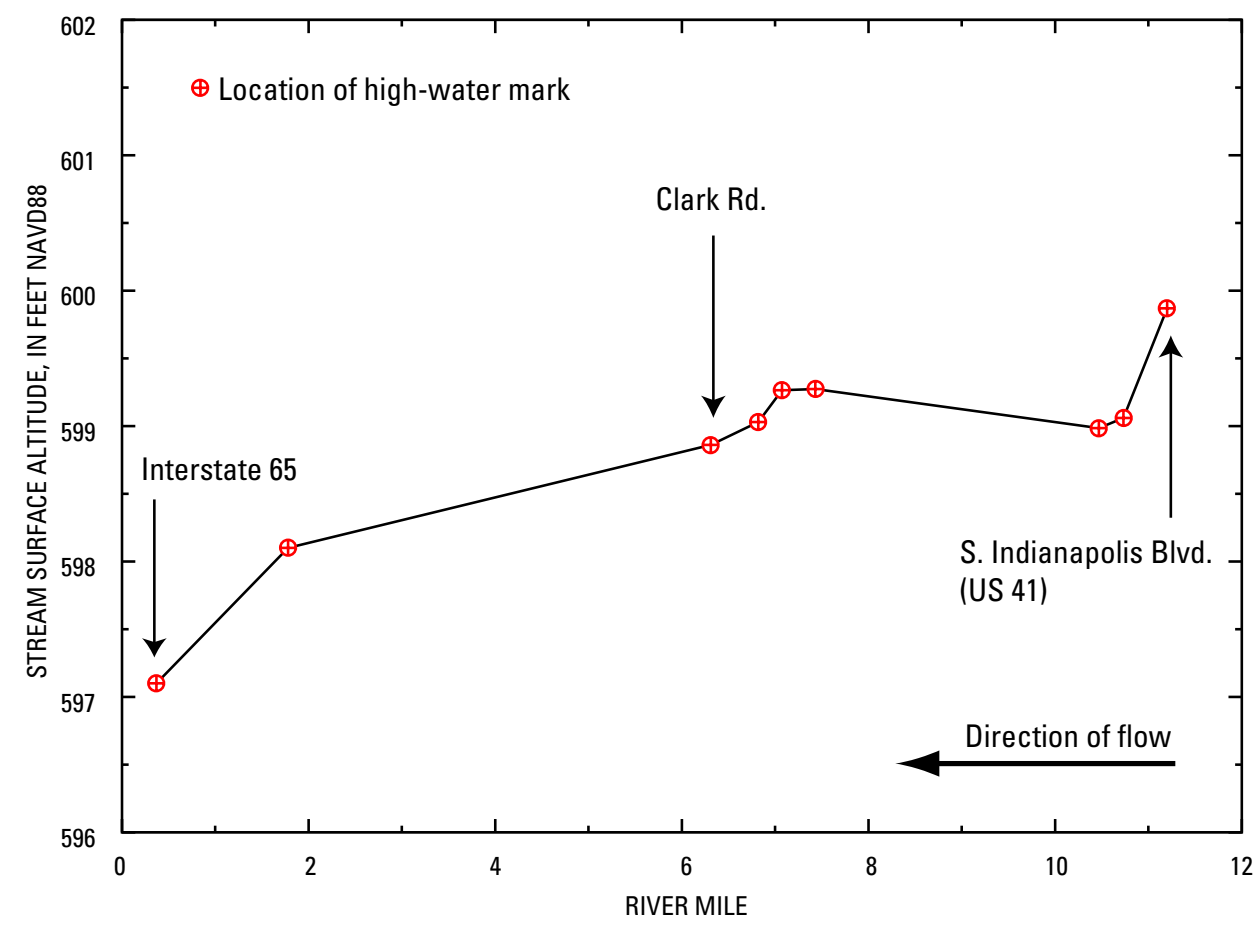

Flood-peak elevation profile, flood of September 2008, for Little Calumet River near Highland, Indiana. 


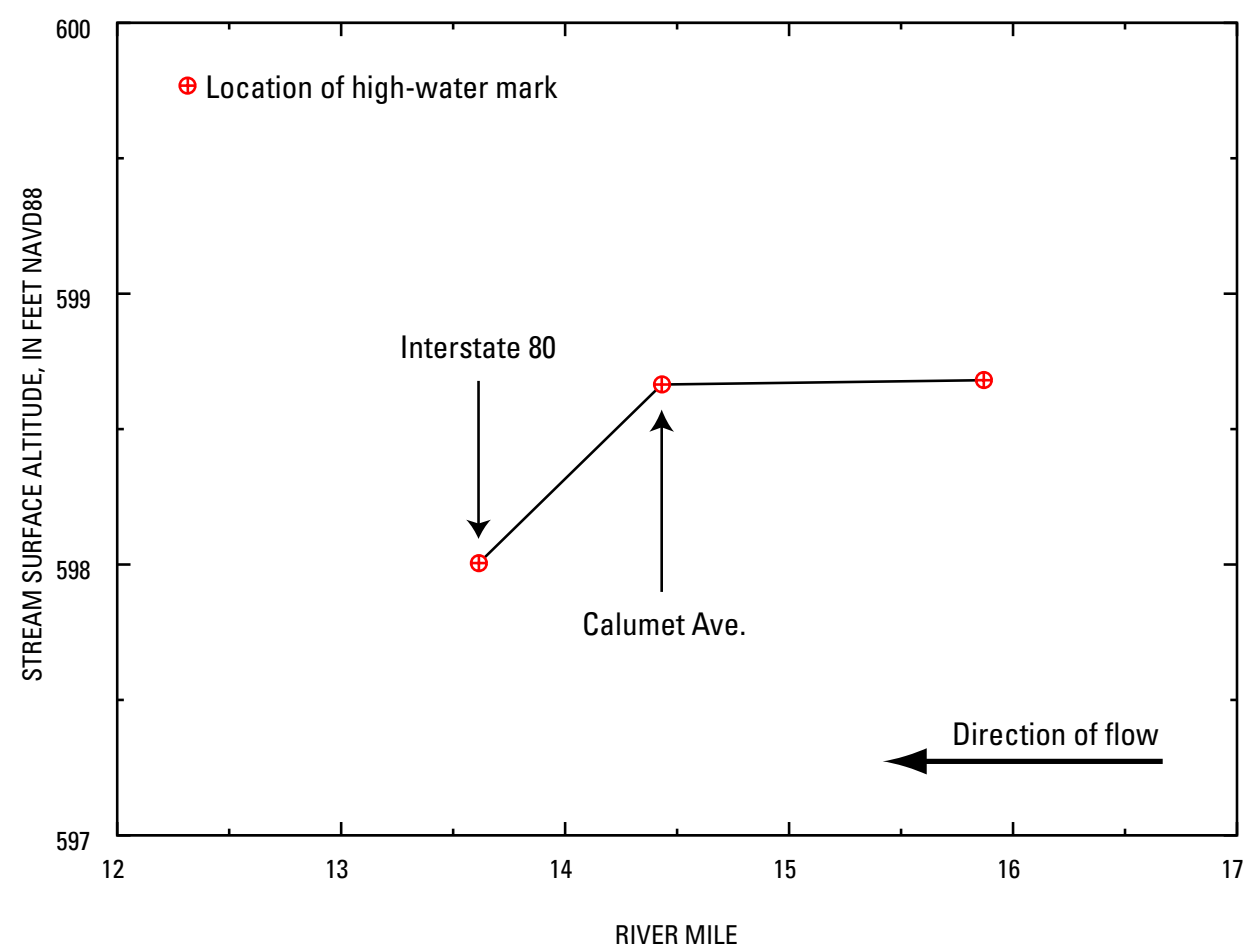

Flood-peak elevation profile, flood of September 2008, for Little Calumet River near Munster, Indiana.

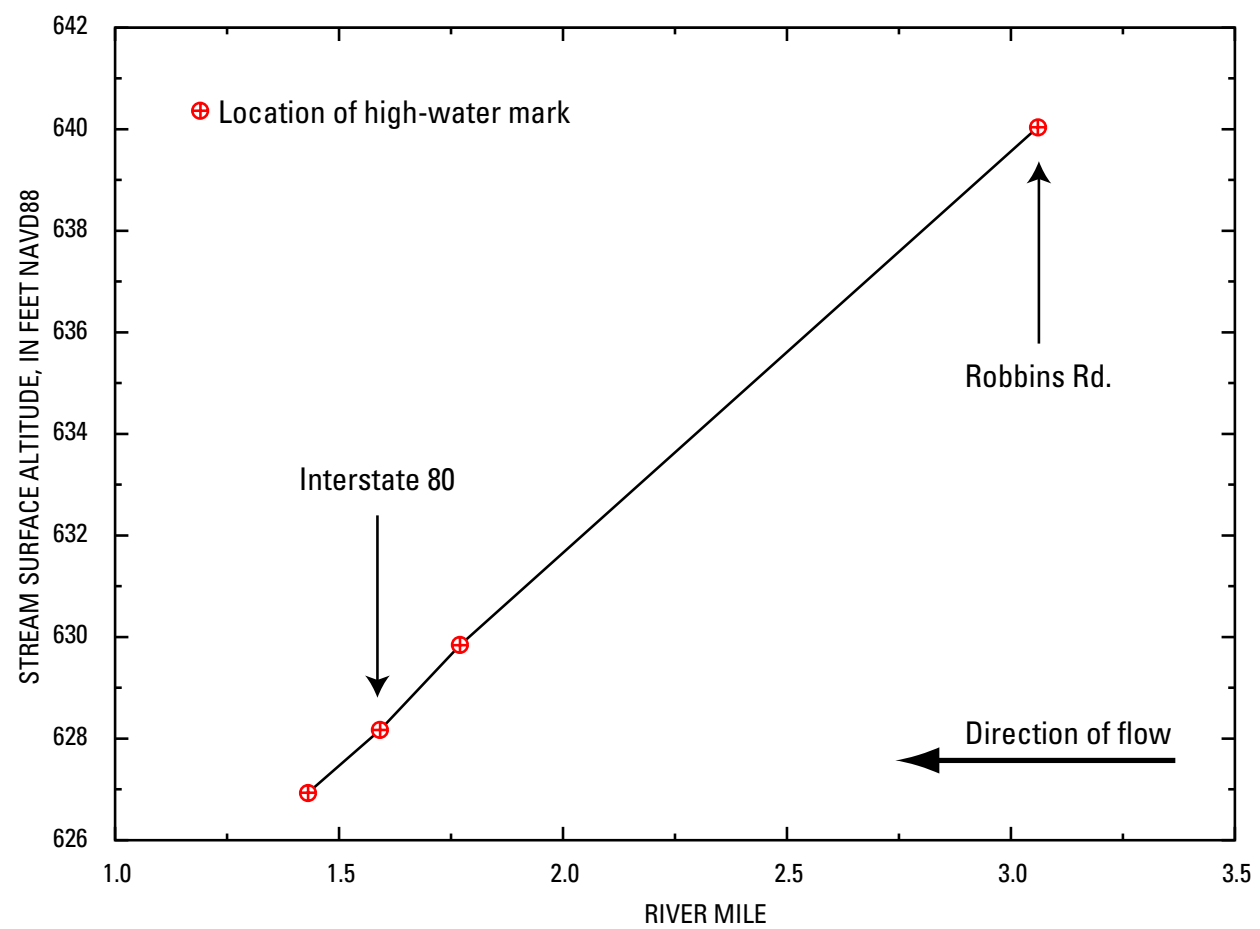

Flood-peak elevation profile, flood of September 2008, for Robbins Ditch near Portage, Indiana. 


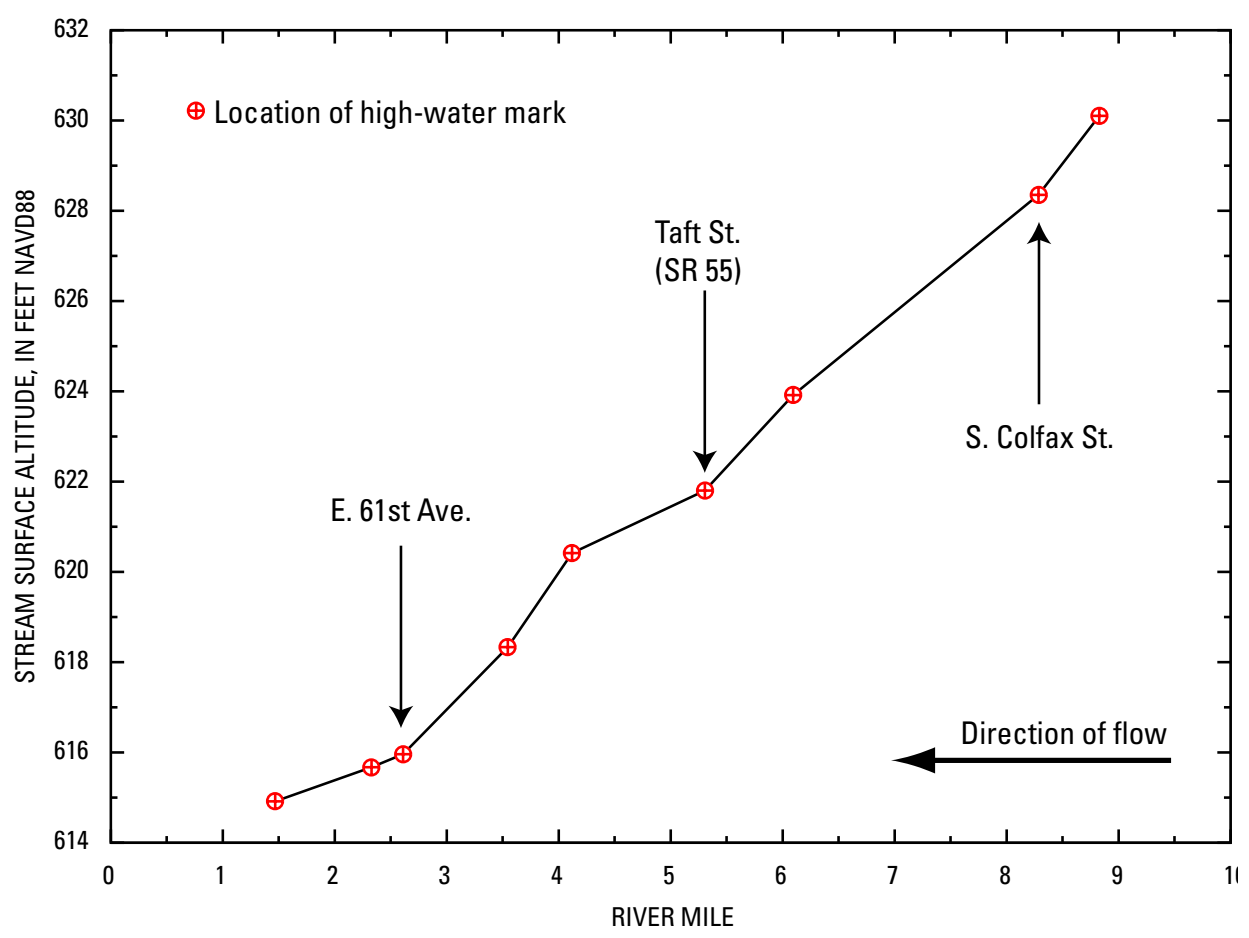

Flood-peak elevation profile, flood of September 2008, for Turkey Creek near Schererville, Indiana.

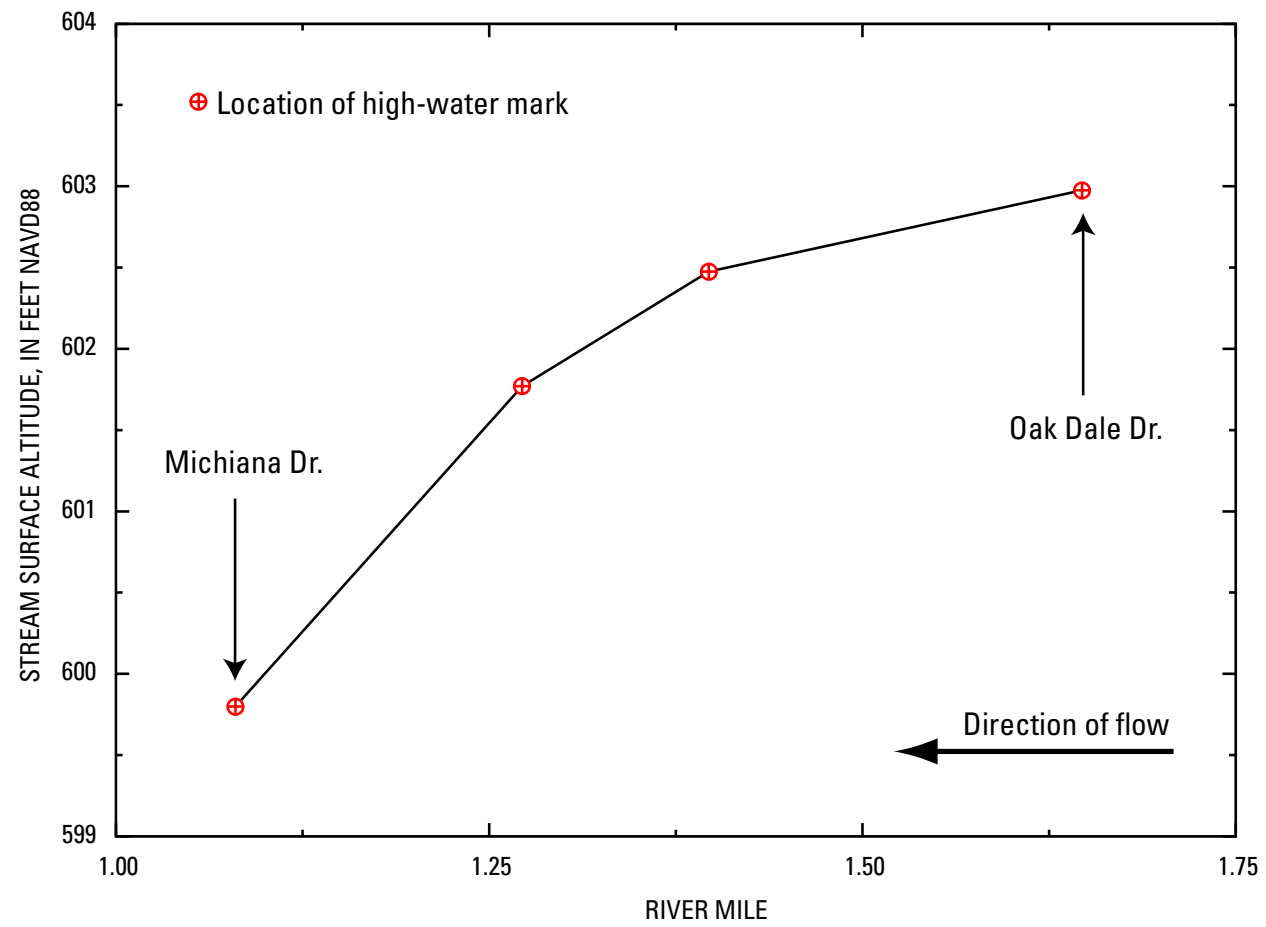

Flood-peak elevation profile, flood of September 2008, for White Ditch at Michiana Shores, Indiana. 


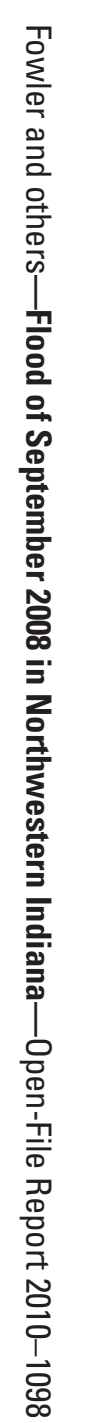

